\title{
Wrestling With Gender: Constructing Masculinity By REFUSING TO WRESTLE WoMEN
}

\author{
Deborah L. Brake*
}

In February of 2011, a high school boy captured national media attention when he refused to wrestle a girl at the Iowa State wrestling championship tournament. Two girls had qualified for the state tournament that year in Iowa, a state where wrestling has an ardent following. But, when Joel Northrup was paired against one of the girls, Cassy Herkelman, in the first round of the 112pound weight class, he decided to forfeit the match rather than wrestle a girl. According to media reports, before he forfeited, Northrup had been a favorite to win his weight class. ${ }^{1}$ The incident launched a brief but intense media frenzy, with coverage in major television and print outlets. The general tenor of the stories portrayed the boy and his father who supported him as heroes in a drama about sacrificing a boy's chance to be a state champion for the welfare of a girl. ${ }^{2}$ The storyline set up a familiar conflict juxtaposing the religious values of the boy and his family against the girl's quest for equal opportunity. ${ }^{3}$ This is a common frame for neutralizing a gender equality claim, by offsetting it with the assertion of contrary religious beliefs. At the same time, the stories about the incident diffused this conflict by casting doubts about the girl's agency, suggesting that the boy and his father were acting in her real best interests. ${ }^{4}$ Other aspects of the incident also fueled the backlash narrative that emerged from the story: the semblance of formal equality (the boy opted out, neither Joel nor Cassy had the opportunity to wrestle), and the appropriation of feminist-sounding messages toward non-feminist ends (men should not hit women;

* Professor of Law and Distinguished Faculty Scholar, University of Pittsburgh. Many thanks to the participants at faculty workshops at the University of Cincinnati and the University of Pittsburgh, where I presented earlier drafts of this article in the Fall of 2011; and to Martha Chamallas, for inviting me to present it to her feminist legal theory seminar students at Harvard Law School in Spring 2012. This article benefited from research assistance from Caitlin Norton and Sarah J. Ratzkin.

1 Mara Gay, High School Wrestler Forfeits Match Rather Than Face Girl, AOL News (Feb. 17, 2011, 5:09 PM), http://www.aolnews.com/2011/02/17/high-school-wrestler-joel -northrup-forfeits-match-rather-than-fa/.

2 See Editorial, A Matter of Conscience, Respect, GAZETTE (Iowa) (Feb. 19, 2011, 12:57 AM), http://thegazette.com/2011/02/19/a-matter-of-conscience-respect/; see also Fred Bowen, Honoring Your Beliefs Makes You a Winner, WAsh. Post, Feb. 24, 2011, at C10.

3 See Bowen, supra note 2, at C10; Jere Longman, On Mat, Girls Still Face Uphill Struggle, N.Y. Times, Feb. 28, 2011, at D1; Luke Meredith, Boy Opts Not to Wrestle Girl at Iowa Tourney, Telegraph Herald (Iowa), Feb. 18, 2011, at A1.

4 Betsy Hart, In Iowa, Chivalry Goes to the Mat, Chi. Sun-Times, Mar. 2, 2011, at 4. 
girls deserve their own matches). ${ }^{5}$ Lost in the media's framing of the story are the deep and implicit connections between sport and masculinity that lie at the heart of this episode. Both the incident itself and the media reactions to it raise questions about the law's ability to guarantee equal competitive opportunities for girls and, broader still, about the role of law in contesting and transforming gender norms.

The narratives that emerged from the media telling of this story reveal a struggle over cultural understandings of gender. In such struggles, there are opportunities but also risks in using law to transform gender norms. The legal issues raised by this incident concern the role that Title IX and the Equal Protection Clause might play in requiring opportunities for mixed-sex competition in a contact sport such as wrestling, and in particular, whether the decision of a school and/or athletic association to permit a boy to forfeit a match because of his opponent's sex, without disqualifying him or otherwise restricting his participation, discriminates on the basis of sex. As I argue below, there is a plausible legal argument that it does. But, more importantly, the episode provides a productive launching point for exploring the role of law in challenging conventional understandings of gender and navigating the backlash against challenges to what sport sociologists have called "the gender order." Such an undertaking requires attention to how the dominant norms of masculinity are constructed and reinforced, and then asking how law might intervene in that process.

This Article uses the Iowa wrestling controversy as a vehicle for identifying and reflecting upon cultural resistance to gender equality in sport, and, more broadly, upon the fault lines that threaten to derail gender equality projects. Part I sets the stage for the controversy by reviewing the relatively recent entry of girls into the sport of wrestling. It discusses the social context surrounding mixed-sex wrestling, the growth of girls' participation in the sport, why girls wrestle, and the role of mixed-sex competition in their development as wrestlers. It also sketches the cultural resistance to girls' participation in wrestling, including the rising phenomenon of forfeiture.

Part II takes a critical look at the media coverage of the Iowa incident to better understand how that framing serves to preserve traditional understandings of gender. ${ }^{7}$ It identifies four ways in which the dominant narrative of the forfeiture undercuts a pro-equality agenda for girls and women in sport: (1) religion and morality are cast as oppositional to, and at least as weighty as, equal opportunity for girls; (2) the agency of the person challenging traditional gender roles (the girl) is questioned, while the authenticity of the agency of persons defending traditional gender meanings (the boy and his father) is

5 See Elizabeth Scalia, Is Society Purposely Messing with Boys' Heads?, Anchoress (Mar. 18, 2011, 7:14 PM), http://www.patheos.com/blogs/theanchoress/2011/03/18/is-society -purposely-messing-with-boys-heads/; Brian Preece, Girls Have Wrestled in Utah for Nearly Two Decades, Deseret Morning News (Salt Lake City), Feb. 19, 2011.

6 See generally Michael A. Messner \& Donald F. Sabo, Introduction to Sport, Men, AND the Gender Order: Critical Feminist Perspectives 1, 11-12 (Michael A. Messner \& Donald F. Sabo eds., 1990).

7 Cf. Reading Sport: Critical Essays on Power and Representation (Susan Birrell \& Mary G. McDonald eds., 2000) (taking a critical cultural studies approach to "reading" media coverage of sports, focusing on the importance of the intersecting power lines of gender, race, and class). 
assumed; (3) "opting out" (a form of "leveling down") appears to be consistent with equal opportunity and therefore not amenable to charges of discrimination or sexism; and (4) de-contextualized strands of feminism are strategically appropriated to expose and exploit tensions within feminism, and then used to defend traditional gender relations. In the forfeiture incident, each of these four "moves" occurred in the specific context of wrestling, but they are mainstays in social conflict over gender roles in other settings as well. Studying the controversy over the wrestling forfeiture illuminates these "fault lines" in contests over the meaning of gender and contributes to a conversation about the risks and potential gains in using law to pursue a feminist agenda.

After elaborating these four tools of the backlash, the Article turns to consider how law might intervene in this story to open up more space for contesting gender norms in sport. The focal point is Title IX of the Education Amendments of 1972, the primary federal law for redressing sex discrimination in school-sponsored athletic programs and, to a lesser extent, the Equal Protection Clause of the Fourteenth Amendment to the Constitution, which restricts sex-based discrimination by state actors, including public schools. ${ }^{8}$ Part III draws on doctrine under Title IX and the Equal Protection Clause to craft a legal argument that a school district or athletic association that acquiesces in boys' gender-based forfeitures of wrestling matches against girls amounts to unlawful discrimination against girls on the basis of sex. Although such an argument has several doctrinal hurdles to overcome, the weight of authority supports placing a legal obligation on schools and athletic associations to discourage gender-based forfeitures in order to provide equal competitive opportunities to female athletes.

With a legal argument in tow, Part IV then considers the question of whether invoking the law in this way has the potential to change the cultural understandings of gender that emerge from stories like the Iowa forfeiture incident and promote gender equality in sport. This question requires going beneath the fault lines discussed in Part II to unearth the masculinities being constructed through the forfeiture event. This Part argues that what is really at stake in the incident is the construction of masculinity, both the masculinity of the forfeiter and the masculinity of the sport of wrestling - a masculinity that is deeply threatened by mixed-sex wrestling competition. The key question then becomes whether the intervention of law has the potential to open up greater space for the development of alternative masculinities in sport that are not rooted in separation from, and superiority over, the feminine, and which allow for greater gender equality in sport. I ultimately argue that law has a potentially useful, albeit limited, role to play in incentivizing alternative masculinities that are more compatible with gender equality, and specifically, with mixed-sex competition in contact sports like wrestling. Changing the kind of socially valued masculinity that sport confers on boys is no small task, but it is critical if further progress is to occur toward gender equality, both in and out of sport.

8 U.S. Const. amend. XIV, § 1; 20 U.S.C. § 1681(a) (2012). 


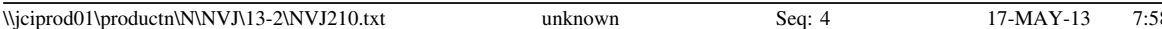

Winter 2013]

\section{Going to the Mat: Girls, Wrestling, and Resistance}

The sport of wrestling has always been a volatile one for gender relations. Wrestling is a sport rife with gender tensions and contradictions. On the one hand, it is a quintessential contact sport, one of the warrior sports, with strong associations with masculinity. ${ }^{9}$ Wrestlers grapple face to face, using strength, force, and skillful moves to battle their opponents at close range. ${ }^{10}$ Like other contact sports, participants risk injury and must have a high threshold for pain. ${ }^{11}$ At the same time, the sport's masculine identity is a precarious one. Wrestling tends to draw boys who are too short or lightweight to be competitive in sports with the strongest connection to masculinity, football and basketball. Since wrestlers are grouped into weight classes, smaller, lighter boys are not held back by their body type. ${ }^{12}$

The sport also struggles with what might look to an outsider like a homoerotic aesthetic. Wrestlers wear body-hugging lycra singlets, and up-close bodily encounters are a major part of the sport, requiring all kinds of intimate and (to observers) awkward positions. In the culture of sport that has taken hold since sports were first introduced in U.S. schools (largely for the very purpose of inculcating masculinity in boys), a sport's masculine identity is inextricably bound up in its power to confer on its male participants a prized hetero-masculinity. ${ }^{13}$ For wrestling especially, this has required the sport to actively distance itself from any suggestion of sexuality or homoeroticism. And yet, the sport's susceptibility to a sexualized understanding can make the uninitiated spectator uncomfortable and its participants defensive. Even the lingo of the sport is loaded with possible double entendres suggesting an undercurrent of sexuality (e.g., "wrestling up the backside," "high crotch takedown," the "butt grab"). Wrestlers themselves, along with their coaches and educated fan base, know that the extraordinary, undivided focus required to compete in the sport leaves little room for distracting feelings of attraction or desire in the heat of a match. Still, more so than for other sports, the potential is there for sexualizing the sport in a way that is inconsistent with maintaining a strong hetero-masculine identity for the sport and its participants. ${ }^{14}$

According to sport and gender scholars Theresa Walton and Michelle Helstein, wrestling's role in recent decades as the leader of the opposition to Title

9 See Laurel Halloran, Wrestling Injuries, 27 Orthopaedic Nursing 189, 189 (2008); Mari Kristin Sisjord \& Elsa Kristiansen, Elite Women Wrestlers' Muscles: Physical Strength and a Social Burden, 44 Int'L Rev. FOr Soc. Sport 231, 231 (2009).

10 Halloran, supra note 9, at 189.

11 See id. at 189-90.

12 Id. at 189.

13 See Marie Hardin \& Jennifer D. Greer, The Influence of Gender-Role Socialization, Media Use and Sports Participation on Perceptions of Gender-Appropriate Sports, $32 \mathrm{~J}$. Sport Behav. 207, 209 (2009) (discussing the process by which sports acquire a gender identity); see also Sally R. Ross \& Kimberly J. Shinew, Perspectives of Women College Athletes on Sport and Gender, 58 Sex Roles 40, 41-42 (2007).

14 See Theresa Walton, Pinned by Gender Construction?: Media Representations of Girls' Wrestling, 14 Women Sport \& Physical Activity J. 52, 58 (2005). 
IX is indicative of the sport's "gender trouble." 15 Wrestling has taken the lead in advocacy blaming Title IX for cuts to men's sports, including and especially to the sport of wrestling itself. Walton and Helstein explain this dynamic in terms of the gendered hierarchy within men's sports, in which wrestling is subordinated to the more masculine sports of football and basketball. ${ }^{16}$ On average, these sports consume the vast majority of the total men's athletic operating budget in universities. ${ }^{17}$ Since Title IX sets limits on cutting women's sports where women already have fewer opportunities to play than men, the excesses of football and men's basketball budgets tend to squeeze out the budgets of other men's sports such as wrestling. ${ }^{18}$ And yet, by choosing to align itself with the "big boys" of football and men's basketball in the Title IX culture wars, wrestling bolsters its masculine credentials, building "community" among wrestlers through an identity that is oppositional to girls' and women's participation in sport, and in line with hegemonic masculinity. ${ }^{19}$ In keeping with this stance, and more so than other sports, many wrestlers and supporters of wrestling have reacted strongly and negatively to the increasing participation of girls and women in the sport.

In recent years, the accelerating entry of girls and women into the sport of wrestling has added fuel to these fires of gender conflict. Girls' and women's participation in wrestling has grown rapidly in recent years, sparked by the addition of women's freestyle wrestling as a new Olympic Sport in the 2004 Olympics, and five years earlier, by the U.S. women winning the 1999 World Championship title in women's wrestling. ${ }^{20}$ Despite growing interest in the sport, however, girls and women typically do not have their own teams. In order to participate in the sport, they have to wrestle male opponents. This has provoked a great deal of resistance, including most recently in the form of forfeiture by male wrestlers.

A quick look at the numbers shows girls' wrestling on a steep upward trajectory. In 1990, 112 high school girls participated in competitive wrestling nationwide. ${ }^{21}$ By 2011 , that number was over $7,000 .{ }^{22}$ The areas where girls' wrestling numbers are highest, however, are not the same as the hotbeds of

15 Theresa A. Walton \& Michelle T. Helstein, Triumph of Backlash: Wrestling Community and the "Problem" of Title IX, 25 Soc. SpORT J. 369, 378 (2008); see generally Judith Butler, Gender Trouble (2d ed. 2007).

16 Walton \& Helstein, supra note 15 , at 381 .

17 Id.

18 See Deborah L. Brake, Getting in the Game: Title IX and the Women's Sports Revolution 74, 217-18 (2010); see also Deborah Brake, Forum: The Two Title IX's, PitTsBURGh Post-Gazette (Feb. 9, 2003), http://old.post-gazette.com/forum/comm/20030209ed brake09p3.asp.

19 Walton \& Helstein, supra note 15 , at 377.

20 Moira E. Stuart \& Diane E. Whaley, Resistance and Persistence: An Expectancy-Value Approach to Understanding Women's Participation in a Male-Defined Sport, 14 WomeN Sport \& Physical Activity J. 24, 25 (2005).

21 Gary Mihoces, Girls Grapple with Success Against Boys, USA TODAY (Mar. 4, 2005, 2:27 PM), http://usatoday30.usatoday.com/sports/preps/wrestle/2005-03-03-girls-wrestling X.htm.

22 2011-2012 High School Athletics Participation Survey, Nat'l Fed'N of State High Sch. Athletic Ass'ns, http://www.nfhs.org/WorkArea/linkit.aspx?LinkIdentifier=id\&Item $\mathrm{ID}=5751 \&$ libID=5773 (last visited Mar. 6,2013$)(8,235$ is likely a low number, since the 
boys' wrestling (the Midwest and East Coast). ${ }^{23}$ Girls' wrestling has had its greatest growth in areas where wrestling is not as emphasized, such as California (near the top of the list, with 1,910 high school girls participating), and in states that offer a separate girls' championship tournament, such as Texas (with more than 1,700 girls in high school wrestling). ${ }^{24}$ However, most states do not have separate wrestling championships or separate competitions for girls. ${ }^{25}$ And, despite their growing numbers, girls are still only two percent of all high school wrestlers. ${ }^{26}$ As a result, girls must wrestle boys if they are to have the opportunity to participate in the sport. ${ }^{27}$

Girls who stay in contact sports like wrestling must overcome negative cultural stereotypes associated with women in the sport and weather a variety of forces that coalesce to suppress female sports participation in early adolescence. Sport scholars have long known that girls' athletic participation declines in adolescence, and especially so for sports identified as "masculine." 28 Girls are less confident than boys in performing masculine-typed tasks, and gender stereotypes begin to influence physical activity choices at a young age. ${ }^{29}$ The research in sport and gender studies also documents differential parental support and encouragement of sons and daughters, with parents spending more time and effort supporting and playing sports with their sons than their daughters. ${ }^{30}$

For girls and women to participate in a male gender-typed sport such as wrestling, they must perceive enough positive benefits to overcome these negative cultural influences. ${ }^{31}$ For the girls who do, they are drawn to wrestling for a variety of reasons. Through wrestling, girls learn to defend themselves and be more assertive, showing boys that they can be strong and worthy opponents. ${ }^{32}$ As one woman training with the U.S. Olympic Training Center (USOTC) said, "[i]t kinda pushes me and makes me feel like I can do anything I put my mind to." 33 Many girls say that they are drawn to the sport because it suits their body

numbers come from competition at the high school level, and many schools report zero girls in wrestling. While the numbers in those schools may be low, they are likely not zero).

23 Walton, supra note 14 , at 56.

24 2011-2012 High School Athletics Participation Survey, supra note 22; Walton, supra note 14, at 57 (stating that Texas created separate wrestling competitions for girls specifically to keep boys and girls from wrestling together).

${ }^{25}$ Longman, supra note 3, at D1 (citing California, Hawaii, Tennessee, Texas and Washington as the only states that offer separate high school wrestling teams and championships for girls).

${ }^{26} I d$. (stating that the number of male high school wrestlers is 270,000 , while 6,000 women competed in high school wrestling in 2009-10).

27 Tamar Lewin, In Twist for High School Wrestlers, Girl Flips Boy, N.Y. Times, Feb. 17, 2007, at A1.

28 For a research study on female members of USA women's wrestling team on why they wrestle see Stuart \& Whaley, supra note 20, at 24.

29 Id. at $25-26$.

30 Id. at 37.

31 Id. at 26 (discussing the literature on motivation and the expectancy-value theory, which takes into account the influence of gender role beliefs and cultural beliefs).

32 See Walton, supra note 14 , at 63-64.

33 Stuart \& Whaley, supra note 20, at 35 (internal quotation marks omitted). See also Vincent Thomas, They're Holding Strong; More Female Wrestlers Going to the Mat Despite Mixed-Sex Issues, WAsh. Post, Mar. 26, 2004, at D1 (statement of female wrestler on why 
type and their temperament. One female wrestler tapped for Olympic training explained, "I was looking for something to do to work out over the winter and I kind of always wanted to try wrestling because I am a very hands-on, physical person." 34 Others explain that they chose the sport because it provides them with the ultimate mental and physical challenge. ${ }^{35}$ It is also attractive as a sport that allows athletes to stand out individually while still being part of a team; and as a newer sport, it offers relatively high chances for Olympic success in comparison to other, more established sports. ${ }^{36}$

These distinctive features make wrestling a potentially rewarding sport for girls and women. In one of the few studies of female wrestlers' experiences, researchers found that the girls and women in the study expressed a greater degree of comfort with their bodies and experienced wrestling as a source of both physical and mental empowerment. ${ }^{37}$ Interestingly, this study turned up a finding that departs from other research findings that female athletes engage in what sport scholars call an "apologetic," in which female athletes emphasize their femininity to compensate for a gender role conflict that arises when they participate in sports, especially in sports gender-typed as masculine. ${ }^{38}$ The female wrestlers in this study did not perceive such a role conflict, and did not consciously try to overcome negative stereotypes associated with female wrestlers by ramping up their femininity off the mat. ${ }^{39}$ In contrast to the low figure

she wrestles: "Wrestling is such a dynamic sport . . . It's like a clash of wills, and it forces you to learn how to conquer yourself and be in control mentally and physically.").

34 Harold Raker, High School Wrestling: Selinsgrove's Spiegel Closer to Olympic Dream, Daily ITEm (Sunbury, Pa.), June 30, 2010.

35 Lewin, supra note 27, at B4 ("Jessica, a soft-spoken girl who braids and pins up her hair before each match, says wrestling has helped build her confidence, challenging both her body and her mind.").

36 Paige Parker, Taking Down the Naysayers: Pacific University's Women Wrestlers Win Respect from Their Male Counterparts, Sunday Oregonian, Jan. 6, 2002, at D1 (citing these reasons why women choose the sport).

37 Ellen Macro, Jennifer Viveiros \& Nick Cipriano, Wrestling with Identity: An Exploration of Female Wres[t]lers' Perceptions, 18 Women Sport \& Physical Activity J. 42, 48 (2009). The subjects of the study were forty-seven Canadian female wrestlers at the high school, college, and club/community level. Id. at 42. Although the subjects were Canadian and their experiences might differ from female wrestlers in the United States, the authors noted similarities in the position of female wrestlers in the two countries. As in the United States, Canadian girls and women are newer and nontraditional participants in the sport, and, due to insufficient numbers of female opponents, must typically compete against boys and men. The finding on the wrestlers' comfort with their bodies was based on measures of their expressed comfort showering in the presence of others (including three different groups of "others": teammates, wrestlers not on their own team, and non-wrestlers) and their comfort levels in other situations (being in a sauna, being weighed, and being seen by others while being weighed, and being seen in public while wearing a singlet). Id. at 45 . The wrestlers also expressed high levels of satisfaction with how they looked in general. $I d$. at 46.

38 Id. at 48-49. The researchers contrasted their findings with previous research on soccer players (citing studies from 2000 and 2005), finding female soccer players felt more inhibited about their bodies and expressed greater anxiety about their body fat. Id. at 47 . Compared to these findings, the wrestlers were more confident about their bodies, and attributed their confidence to wrestling. $I d$.

39 Id. at 48. Among the data relevant to this finding, ninety-four percent of the female wrestlers in the study said that they were not worried about personally being stereotyped as lesbian because of their participation in wrestling, and seventy-four percent said that they did 
of six percent of female wrestlers in this study who said that they were concerned about being labeled "lesbian" because of their sports participation, a majority of the subjects in other studies of female athletes (soccer players and boxers) have expressed this concern. ${ }^{40}$ Speculating on the reasons for this, the researchers noted several possible explanations for this discrepancy, including the fact that female wrestlers may be better able to resist a perceived gender role conflict. ${ }^{41}$ Notably, the wrestlers in the study claimed that they viewed wrestling as a sport that is appropriate for women, and not a masculine sport at all, while nevertheless acknowledging that the general population perceives it as a masculine sport. ${ }^{42}$ The study portrayed these women as actively resisting popular gendered understandings of wrestling and substituting their own views of the sport's suitability for girls and women.

Another study of female wrestlers, this one focusing on elite women wrestlers training for the U.S. Olympic tryouts, likewise found that the female wrestlers in the study built a strong and empowering identity for themselves as wrestlers. ${ }^{43}$ These women too were aware that wrestling is stereotyped as a masculine sport, but persisted in the sport anyway, choosing for themselves alternative definitions of what it means to be feminine. ${ }^{44}$ As one female wrestler explained:

"I know that society thinks that girls' wrestling is not feminine. My dad thinks being feminine is wearing a dress, but my mom thinks it's being in charge of yourself and being confident." ${ }^{.45}$ Another wrestler added her own redefinition of femininity: "I think femininity is about how you carry yourself on and off the mat. I don't have to have my nails done and wear makeup everyday to be feminine. Even though I'm sweating and my shirt is all torn up, I'm still feminine." ${ }^{46}$ This study too found the female wrestlers actively engaged in a process of constructing their own identities and resisting interpretations of female wrestling as inconsistent with femininity. ${ }^{47}$

The findings of these studies are consistent with how female wrestlers describe themselves and their decision to wrestle in news reports on female wrestlers. As one high school wrestler said, defending her right to compete, "I think it's really important, because you shouldn't stereotype a sport. Guys and girls can do any sport they want." 48 The two female wrestlers interviewed in

not try to compensate for being a wrestler by playing up their femininity (wearing long hair, feminine clothes, make-up, etc.). $I d$. at 46-47.

$40 I d$. at 47. Similarly, fewer than half of the wrestlers said it was important to them to be perceived as feminine, contrasting with much larger numbers on research on other athletes. Id. at 48 .

41 Id. at 49.

42 Id. at 48.

43 Stuart \& Whaley, supra note 20, at 36.

44 Id. at 33.

$45 I d$.

$46 I d$.

$47 \mathrm{Id}$.

48 Meera Patel, Editorial, Girls Grapple with Sexism in Sports, Indianapolis Star, Apr. 20, 2008 , at 4 . 
the story said that the sport made them "stronger, better athletes and more goaloriented." 49

Still, even if the female apologetic is more variable now than when it first surfaced in the literature, and even if female athletes differ in how they experience and navigate gender role conflict, female wrestlers too must navigate conflicting expectations about ideal femininity (an ideal with implicitly white and heterosexual markers, such as having long hair, and being attractive to and attracted to men) while engaging in athletic performances that clash with this ideal. As the sport/gender scholarship has shown, even though the dominant cultural ideal of femininity has expanded to embrace fitness, firm bodies, and athleticism, it still punishes women whose athletic performances and/or bodies go too far in pressing against the boundaries of white hetero-feminine norms. ${ }^{50}$ Girls and women who play masculine-typed sports are especially likely to be caught in this role conflict and to engage in "impression management" in order to avoid or mitigate the stigmas of mannishness and lesbianism. ${ }^{51}$ This dynamic in the sport/gender literature is similar to the discussion of identity performance and "covering" discussed in legal scholarship-efforts undertaken by members of subordinated groups in a variety of settings and in contextspecific ways to make their identities more palatable to controlling majority groups. ${ }^{52}$

Notwithstanding the study (discussed above) of elite female wrestlers claiming that they did not engage in actions to compensate for their participation in wrestling, news stories abound with examples of what could be called "identity management" by female wrestlers. For example, one story about a female high school wrestler in Pennsylvania softened its account of a female wrestler's proficiency with a quote from the girl saying, "I may be a little rougher than some of my girl friends, but when I'm not wrestling, I go to the mall, I talk about boys, and I worry about my hair." 53

The persistence of gender role conflict for girls and women who wrestle can also be seen in defenses of female wrestlers by their supporters. Proponents of girls' wrestling almost invariably feel compelled to defend the girls' femininity, and implicitly, their heterosexuality. For example, one wrestling coach who had coached girls on his team wrote a letter to the local newspaper in the wake of the Iowa forfeiture controversy responding to comments by other readers wondering, "what kind of girls would wrestle?" The coach responded that the four girls he coached grew up to be "solid citizens," emphasizing that "[a]ll of them got married." $54 \mathrm{He}$ also confided that he himself had asked the girls why they wanted to wrestle, and shared one girl's answer that she was not good

$49 I d$.

50 Macro, Viveiros, \& Cipriano, supra note 37, at 43; see also Ross \& Shinew, supra note 13, at 53; Amanda Roth \& Susan A. Basow, Femininity, Sports, and Feminism: Developing a Theory of Physical Liberation, 28 J. SPORT \& Soc. Issues 245, 252 (2004).

51 Macro, Viveiros, \& Cipriano, supra note 37, at 44.

52 See, e.g., Devon W. Carbado \& Mitu Gulati, The Fifth Black Woman, 11 J. ContemP. Legal Issues 701, 701-03 (2001); Kenji Yoshino, Covering, 111 Yale L.J. 769, 772 (2002).

53 Deborah Weisberg, Hampton Girl Making a Name for Herself, PitTsBurgh PosTGazetTe, June 14, 2000, at N12.

54 Preece, supra note 5. 
enough to make the varsity team in any other school sport. ${ }^{55}$ In this exchange, the girl's lack of competence in other sports serves the purpose of making her decision to wrestle more acceptable. Although the coach expressed his support for girls in wrestling, his defense ultimately reinforced the cultural ambivalence about girls' wrestling by reaffirming that a girl's decision to wrestle requires an explanation. ${ }^{56} \mathrm{He}$ also, tellingly, expressed the wish that there were enough girls in the sport so that girls did not have to wrestle boys. ${ }^{57}$ It is a common refrain of supporters of girls' wrestling, even as they defend girls' right to wrestle boys, that it would be better if girls had their own teams. ${ }^{58}$ Girls themselves often deflect criticisms of their participation in the sport by emphasizing that they had no choice but to wrestle boys, since the lack of female competition meant that they could not otherwise participate in the sport. ${ }^{59}$

Other signs of ambivalence, if not outright hostility, to girls' participation in wrestling abound. Mixed-sex wrestling matches often prompt negative publicity, ${ }^{60}$ and the NCAA still has not recognized wrestling as an emerging women's sport, despite their recognition of "emerging sports" with much lower levels of female high school participation. ${ }^{61}$ And, despite the likely illegality of such practices under the Equal Protection Clause, which is discussed in Part III below, there have been numerous attempts to impose outright bans on girls from participating on boys' wrestling teams. One such attempt took a dramatic turn when hearings before a committee of the Minnesota legislature took "testimony" in the form of a live wrestling exhibition between two high school boys to demonstrate the physical intimacies involved in certain wrestling moves. ${ }^{62}$ This "testimony" was offered in support of a bill that the Minnesota legislature considered in 2002 to repeal a state law requiring that girls be allowed to try out for boys' teams if they did not have a team of their own in that sport. ${ }^{63}$ The bill was motivated by opposition to mixed-sex wrestling, and its proponents

$55 I d$.

56 Id. See also Parker, supra note 36, at D1 (quoting a wrestling coach who "finds himself reassuring startled listeners that women wrestlers aren't ugly, masculine or dumb," when he mentions that he coaches women wrestlers, he adds, "These aren't the dregs of society .... These are girls you'd be proud to have your sons going with.").

57 Preece, supra note 5.

58 See, e.g., Lewin, supra note 27, at B4 (statement of coach of a successful female wrestler, "I think it's better if it's girl and girl . . . . If boys and girls wrestle together, it's physically harder for the girl, but mentally harder for the boy.").

59 See, e.g., Stuart \& Whaley, supra note 20, at 33.

60 Id. at 25; Parker, supra note 36, at D1 ("Articles about women's wrestling are rife with snide asides about mud and Jell-O.”).

61 Karen Price, NCAA Program Keeps Emerging Sports Alive, TrIB.-Rev. (Pittsburgh), Oct. 11,2011 (the current list of NCAA emerging sports is equestrian, rugby, and sand volleyball, with a proposal pending for triathlon). None of these sports has anywhere near the numbers of female high school participation as wrestling. Women's wrestling is not a recognized sport by the NAIA (National Association of Intercollegiate Athletics) either. NAIA Championship Sports, NAIA EligiBILITY CENTER, http://www.playnaia.org/page/sports.php (last visited Mar. 6, 2013) (women's wrestling not listed).

62 Mark Brunswick, A Touchy Issue: Should Girls Wrestle Boys?; Panel Moves to Repeal Law that Allows for Co-ed Teams, StAR Trib. (Minneapolis), Feb. 20, 2002, at 1B.

${ }^{63} I d$. 
sounded the alarm of sex-panic. The bill was ultimately defeated but takes its place among other widespread efforts to stop girls from wrestling boys. ${ }^{64}$

Where girls have not been kept off boys' wrestling teams (and as discussed below, efforts to do so in public schools have been ruled unconstitutional where girls would otherwise have no opportunities in the sport), forfeiture has become a potent method of resistance. As more girls have gone into wrestling, there have been increasing reports of boys refusing to wrestle female opponents. Boys' stated reasons vary, but typically include the explanation that they would not want to hurt a girl or that it would seem sexually inappropriate. Such refusals result in the boy's forfeiture of the match but are otherwise permitted by schools and athletic associations without penalty-that is, the boy is not disqualified from the tournament, just tagged with a loss.

Wrestling is unlike most other sports in which girls and women participate in that female wrestlers must rely on competition from male opponents in order to develop their skills and compete at a high level. ${ }^{65}$ Male wrestlers who forfeit matches against girls are therefore a significant impediment to female wrestlers' competitive opportunities and a potent form of resistance to girls' entry in the sport. When widespread, such forfeitures can decimate girls' competitive opportunities in the sport. As one high school wrestling coach said of the first girl he ever coached: "I bet she had a dozen forfeits. (Boys) just don't want to be beaten by a girl." 66 Stories abound of female athletes whose competitive opportunities, and therefore skills-development, were significantly impaired because of forfeits by male opponents. ${ }^{67}$ One high school wrestler lamented that, as she got better, she had a harder time finding opponents willing to wrestle her:

What I hate the most though is when people forfeit to me .... That's something I've

kind of had to deal with ever since I started wrestling, just because I'm a girl.

In eighth grade, I was on a junior league team, and in about my first 10 matches

I got forfeits, and it was because I was a girl. I was really disappointed about that.

You put in a lot of effort, and then people just forfeit to you. It didn't happen before I

got good, that's the worst part. ${ }^{68}$

Another high school coach recalled how "one of his former female star wrestlers get [sic] credited with a bunch of forfeit wins because male wrestlers didn't want to be embarrassed by losing to a talented female wrestler." ${ }^{69}$ Even women training for the U.S. Olympic team, who had reached the highest levels

64 See, e.g., Ellen Nakashima, Girls Getting a New Hold on an Old Sport: Some Boys Forfeit Rather than Wrestle, WASH. Post, Feb. 24, 1999, at A1 (identifying two states, South Dakota and Wyoming, with bans on mixed-sex wrestling, and noting as another example of rules against mixed-sex wrestling that the Lutheran High School Association of Greater Detroit requires boys to forfeit matches against girls); see also H.F. 2437, 2002 Leg., 82d

Sess. (Minn. 2002) (Minnesota House Committee recommended that the bill pass on Feb. 20, 2002, but there was no Senate action, and it was not enacted).

65 Stuart \& Whaley, supra note 20, at 34.

66 Chad Garner, Local Athletes, Coaches Debate Issue of Co-ed Competition, SEnTINEL \& ENTERPRISE (Fitchburg, MA), Feb. 26, 2011 (alteration in original).

67 Stuart \& Whaley, supra note 20, at 34.

68 Ryan Young, Wrestling for Respect, One Victory at a Time; Maroulis Excels But Still Searches for Acceptance, WASH. Post, Feb. 16, 2006, at ME18 (internal quotation marks omitted).

69 Garner, supra note 66. 
in their sport, identified lack of competition as a major impediment to their development in the sport, and expressed frustration at being dependent on the men for competition and at having to wait for the men's team to finish their workouts in order to have an opponent to wrestle. ${ }^{70}$

Despite their lukewarm and sometimes outright hostile reception, girls have achieved increasing success on the mat in recent years. Girls have qualified for the state championship in as many as forty-nine states and have placed in at least ten states. ${ }^{71}$ To date, three girls have won state title championships, including, most recently, a Vermont high school girl who beat a boy in the final round to win her state's title match for her weight class just a week after the Iowa forfeiture debacle. ${ }^{72}$ Unlike the male forfeiter in the celebrated Iowa forfeiture, this Vermont state champion was not heralded in an in-depth interview aired on the Cable News Network (CNN). Part II takes a critical look at the media coverage of the Iowa forfeiture using the $\mathrm{CNN}$ coverage as a bellwether of the mainstream media "take" on the event.

\section{Lessons from Iowa (AND CNN): Four Moves for Resisting Threats to the Gender Order}

The media coverage of the Iowa forfeiture decision is itself significant, both for what it says about why one wrestler's decision not to wrestle was worthy of national coverage and for the messages conveyed in that coverage. In the media's summation of the moral of the story, much is revealed about how the gender culture wars are fought and how more progressive understandings of gender are resisted.

\section{A. Media Reaction to the Forfeiture: Reading CNN}

As is evident from the discussion in Part I, the presence of girls in wrestling destabilizes the gendered meaning of wrestling and of sport more broadly. The ability of girls to compete against boys in an intensely physical contact sport like wrestling, whether or not they win, calls into question deeply ingrained linkages between sport and masculinity. These connections have been the subject of extensive scholarship by sport and gender scholars. ${ }^{73}$ The prospect of girls wrestling boys threatens the "gender order" of sport. ${ }^{74}$ It upsets

70 Stuart \& Whaley, supra note 20, at 34 (statement of one woman training with USOTC: "It's difficult ... the way we have to be dependent on the guys to train with us, because there are so few women in my weight class. In some ways it's hard because women seem to fight different than men."). See also Raker, supra note 34 (interviewing a Pennsylvania wrestler recently tapped for Olympic training who described her high school wrestling experience saying that her only wins against boys came by forfeit).

71 Longman, supra note 3, at D1 (citing U.S. Girls Wrestling Association); see also E-mail from Kent Bailo, Founder and CEO of U.S. Girls' Wrestling Ass'n, to author (Apr. 5, 2012) (on file with author).

72 Longman, supra note 3, at D1 (The other two were from Alaska, also winning their title matches against male opponents).

73 See Deborah L. Brake, Sport and Masculinity: The Promise and Limits of Title IX, in Masculinities and the Law: A Multidimensional Approach 207, 209-12 (Frank Rudy Cooper \& Ann C. McGinley eds., 2012) (summarizing and citing this work).

74 See Messner \& Sabo, supra note 6, at 11-12. 
dominant views about gender difference and the existence of a gender binary (with girls on the weak side and boys on the strong side) and interrupts the work sport does in solidifying these understandings. ${ }^{75}$ Moreover, the spectacle of girls wrestling boys brings into sharp relief the physical intimacy of wrestling and triggers a need to reassert the sport's identity as a hetero-masculine activity. As when women integrate other male domains, the presence of women is charged with sexualizing formerly all-male spaces and introducing a taint of sexuality that purportedly did not exist before. ${ }^{76}$ Getting women out of these spaces reasserts the absence of sexuality in all-male spaces and reclaims sport as a non-sexualized, hetero-male domain.

The introduction of alternative, more feminist understandings of gender often triggers a backlash. ${ }^{77}$ In this backlash, existing meanings of gender are reasserted and defended. Examining the media coverage of the Iowa incident reveals some insights into how this struggle over meaning plays out and some of the strategies for resisting progressive understandings of gender.

An interview with Joel Northrup and his father, Jamie Northrup, aired on $\mathrm{CNN}$ shortly after the story broke. The CNN coverage provides a good vantage point for analyzing the media's framing of the forfeiture story. Substantively, CNN's "spin" on the story is representative of the generally positive coverage of Joel Northrup and his decision. And, logistically, the CNN story is an appealing media text to study, because it has a readily available transcript and is viewable online. ${ }^{78}$ Although the forfeiture also generated extensive print coverage, television plays a unique role in constructing and conveying to a wide audience the meanings that shape public understanding. It also provides visual images of the main players in the drama: Joel, his father, and to a much lesser extent, his opponent Cassy.

The story opens with the host, T.J. Holmes, announcing: "A 15-year-old boy made national headlines when he refused to wrestle a girl. He defaulted in a match in the state championship tournament in Iowa, essentially giving up his chance to be state champion. Why did he do that?"79

The host then introduces the boy, Joel Northrup, and his father, Jamie Northrup, who join the program live from a studio in Cedar Rapids, Iowa. The camera opens to two men who appear to be white, clean-cut, neatly dressed, and sporting short hair. After thanking them for being on the program, the host asks Joel why he did not think it was appropriate to wrestle a girl. Joel's

75 See, e.g., David Whitson, Sport in the Social Construction of Masculinity, in SpORT, Men, and the Gender Order: Critical Feminist Perspectives, supra note 6, at 19, 20-24.

76 See Martha Chamallas, The New Gender Panic: Reflections on Sex Scandals and the Military, 83 MinN. L. Rev. 305, 367-68 (1998) (discussing "gender panic" in the military, and explaining how the assumption that women introduce the element of sexuality into this setting leads to the "solution" to get rid of-or at least segregate-women in the military). 77 See generally Theorizing Backlash: Philosophical Reflections on the Resistance to Feminism 3-88 (Anita M. Superson \& Ann E. Cudd eds., 2002).

78 American Morning: Wrestler Who Wouldn't Fight a Girl Speaks About It for First Time (CNN television broadcast Feb. 23, 2011, 9:36 AM), http://am.blogs.cnn.com/2011/02/23 / 15-year-old-wrestler-wont-compete-against-girls/ (transcript available at http://archives.cnn .com/TRANSCRIPTS/1102/23/ltm.02.html).

$79 \mathrm{Id}$. 
response highlights the physical aspect of wrestling: "Well, wrestling is a combat sport. And, at times, it gets violent and you get put in moves and holds that are compromising and I just don't believe it's right that a boy and a girl should, in this manner, wrestle." 80

The host then presses Joel to say why, exactly, the physicality of the sport is problematic between boys and girls, whether it is the violent nature of the sport or the sexual content of the moves:

So is it more so-it sounds like it's a combination, but we know wrestl[ing] can be an up close and personal sport, if you will, and you had to get in all kinds of positions and touch each other in all kinds of places.

Is it more so that what it was? [sic] Or, you just didn't like the idea of a boy, you, having to maybe slam a girl on the mat in a violent way? ${ }^{81}$

Joel responds that it is both. The host then turns to Joel's father, Jamie Northrup, and asks him if he was behind the decision to forfeit or if Joel made the decision on his own. Jamie replies that the decision was Joel's, although his response suggests that parental influence may have played a role, despite his disclaimer that it did not:

Well, we certainly left the decision up to Joel. This is something that Joel has stood by for quite a few years now. We gave him the opportunity and said, Joel, do what you feel is the right choice to make in this particular situation. And so he certainly made his own decision. ${ }^{82}$

Although Jamie insists that it was up to Joel to decide what was right, the rest of the interview leaves no doubt about what Jamie believed was the right decision. His reference to giving Joel "the opportunity" seems to refer to the opportunity to make the right and venerable decision to forfeit, and not to the opportunity to wrestle. ${ }^{83}$

The host then gives Joel a chance to dispel one possible reason for deciding not to wrestle, the fear of being beaten by a girl, "Now, Joel, as well, and I'm sure you heard it probably from some friends of yours and some people around the country have been talking about it. Now, is there any part of you that just didn't want to stand the idea of possibly losing to that girl?" 84

Joel responds, predictably, given the tenor of the interview so far: "No. That didn't play into it. I'm not taking anything away from Cassy, but I wasn't really intimidated at all. But I had already made the decision just not to wrestle her." 85

That is the last word on the possibility of the fear of being beaten by a girl as the reason for the forfeiture, and Joel's dismissal of that explanation seemingly puts to rest that explanation. At the mention of Cassy's name, the host then introduces her with a very brief video clip of Cassy (not live on camera, but pre-recorded) talking about her disappointment at not being able to wrestle. This is Cassy's only appearance in the interview: "I feel like-just having grown up-I feel like people should treat me the same way, like the fact that

${ }^{80} I d$.

${ }^{81} I d$.

82 Id.

83 Id.

${ }^{84} I d$.

$85 I d$. 
I'm doing the same sport as them, that I'm doing the same things as them, like I don't feel I should be much difference there [sic]." 86

In the video, Cassy appears somewhat downcast and inarticulate. Compared to Joel and his father in their live appearance, her voice sounds thin and might be received uncharitably as whiny. The video of Cassy is her only appearance in the interview. It lasts less than fifteen seconds in a segment that is just shy of six minutes. There is no footage of her wrestling, just her standing and talking to the camera. The hosts give no further background on her, nothing to highlight her accomplishment in qualifying for the state championship tournament or her record and experience wrestling against boys.

After the video clip of Cassy ends, the host turns to the subject of coed wrestling, assigning blame for Joel's predicament to the state's lack of separate wrestling matches for girls:

And Joel, once again back to you, wrestling is a big deal in Iowa, and it's unfortunate they don't have a girls-only tournament there. Some places around the country, they do.

But do you think that is unfortunate and that shouldn't be the case where girls are required, they don't have a choice but to wrestle the boys? ${ }^{87}$

Taking the host's lead, Joel agrees: "Yes. Of all sports, wrestling especially, I don't think it should be a coed sport. I believe if girls do want to wrestle, that they should wrestle other girls. And that boys, if they do wrestle, should wrestle other boys." 88

The host then brings up the relevance of religion. He is the first person in the interview to suggest that religion played a role in the decision. He asks Jamie Northrup if he raised his son to be religious and if the decision was based on religious beliefs. Jamie answers affirmatively, saying that religion did play a role:

Well, T.J., certainly faith plays a factor. Even though there's no specific scripture that addresses wrestling with girls, there's a biblical Christian principle of treating women with respect and dignity and not looking at them as objects to be defeated on the wrestling mat, or to be, you know, in some cases, groped or slammed or, you know? ${ }^{89}$

The host then questions Joel if he has ever wrestled a girl, to which Joel replies that he did in third grade, but felt badly about it, and decided afterwards never to do so again. The host next asks Joel if he had a chance to talk to Cassy about his decision to forfeit. Joel replies that he did not talk to Cassy, but that he did speak with her father, and that her father "supported what I did." 90 The host then wraps up the interview by posing a final question to Joel:

I think you're a sophomore now. So you got a couple more years in high school. I'm going to leave it on this question.

Let's say, next year or the year after, your senior year, let's just say your senior year, you go through the state championship tournament, you get to the finals, and to

$86 I d$.

${ }^{87} \mathrm{Id}$.

88 Id.

$89 I d$.

$90 \mathrm{Id}$. 
win the state championship, and for you to be state champion you would have to wrestle a girl to win it.

Would you wrestle it or would you step back and forfeit once again and give up the chance to be state champion?"1

Joel replies resolutely: "Yes, I would give up the chance. I wouldn't wrestle a girl whether it's finals or any other meet or districts, I wouldn't wrestle a girl." 92

The host concludes the segment with unabashed accolades for Joel and his father, and another missive about the unfortunate absence of separate wrestling competitions for girls:

Well Joel, you seem like a young man who is certainly standing by his beliefs. A lot of people applauded the decision you made. Again, it's unfortunate that the kids are put in positions that boys and girls have to wrestle there in your state and many other places.

But, congratulations on the decision. And dad, congratulations to you on your son there. Seems like a good young man. And good luck down the road in your wrestling career. ${ }^{93}$

The tenor of the CNN clip is consistent with most of the mainstream media coverage of the story. Although there were a few negative reactions to the forfeiture decision, especially from other wrestlers and coaches, ${ }^{94}$ mostly the press coverage depicted Joel and his decision in a favorable light. ${ }^{95}$ In a CNN poll reported a few days after that interview, sixty-seven percent of persons responding sided with Joel and his decision to forfeit the match rather than wrestle a girl. ${ }^{96}$

\section{B. Anatomy of a Backlash: Four Ways to Resist Gender Equality}

What strikes me about the forfeiture story as told by CNN is how deftly it averts the threat to conventional gender relations posed by the presence of girls on the mat. This section identifies four strategies-I cannot resist calling them "moves," given the wrestling backdrop-that function in the forfeiture incident to reassert the connections between sport and masculinity that coed wrestling disrupts. These four moves often surface in contests over gender equality and are not unique to the forfeiture controversy.

91 Id.

$92 I d$.

93 Id. Where the transcript departed from the on-line video of the interview, I went by the video. For example, in the transcript, the host compliments Joel that he seems like a "good kid"; but in the video, he clearly says "good young man." Id.

94 Garner, supra note 66 ("Local wrestling coaches, along with former high school wrestlers - one female and one male — said Northrup made a mistake by forfeiting.").

95 The media coverage of this incident was reminiscent of an earlier episode in 1984, when a wrestling coach instructed his wrestlers to forfeit in a tournament that included a female competitor. That forfeiture too made national headlines, celebrating the coach for taking a stand for the good of his students. See Amy Rabideau Silvers, Foti Made News As Coach, Teacher, Milwaukee J. Sentinel, Nov. 11, 2004, at B9 (discussing the incident in an obituary for the coach, Robert Foti, and noting that he "got way more than 15 minutes of fame when he took a stand by having a young wrestler sit down," and describing some of the positive media attention that ensued).

96 Sunday Morning (CNN television broadcast Feb. 27, 2011, 8:00 AM) (transcript available at http://transcripts.cnn.com/TRANSCRIPTS/1102/27/sm.02.html). 
\begin{tabular}{lllll}
\hline |ljciprod01/productn|N\NVJ13-2lNVJ210.txt & unknown & Seq: 17 & 17-MAY-13 & 7:58 \\
\hline
\end{tabular}

\section{Religion vs. Equality}

On the side of Cassy's opportunity to compete in the state championship is a commitment to gender equality and nondiscrimination. On the side of Joel's decision to forfeit stands his religion, which prevents him from wrestling a girl. The two values square off, each neutralizing the other. This is a powerful way to counteract arguments for gender equality since it resonates with deeply held commitments to individual liberty and freedom of conscience. The framing of a struggle over gender equality as one of religious belief versus gender equality is so familiar that the religion side of the equation is often credited as equally (or more) weighty with little or no scrutiny or attention to context. Asserting religion is tantamount to a trump card that beats, or at least equals, gender equality.

The "pull" of religion in this context is so powerful and expected that the CNN host is the first to raise it in the interview, practically reminding Joel and his father to put the decision in religious terms. An article in the New York Times that ran after the $\mathrm{CNN}$ interview also highlights religious reasons for the forfeiture, quoting Joel, who is identified as the son of a minister, as saying:

I have a tremendous amount of respect for Cassy and Megan and their accomplishments . . . However, wrestling is a combat sport and it can get violent at times. As a matter of conscience and my faith, I do not believe that it is appropriate for a boy to engage a girl in this manner. It is unfortunate that $I$ have been placed in a situation not seen in most high school sports in Iowa. ${ }^{97}$

Raising the mantra of religion deflects criticism of the forfeiture decision and rehabilitates it from any charge of discrimination. The New York Times article continues, "[s]ome criticized Northrup for being sexist or afraid of losing," but it then abruptly deflects this criticism by shifting to a boy who lost his state's championship to a girl, quoting him as saying that he too took his religion "very seriously" and did not "blame him [Joel]." 98 In other news articles, too, religion served to deflect criticism of the forfeiture as being sexist. ${ }^{99}$

Framed in this way, as a clash of foundational norms, the interjection of religion as a counterweight to equality creates a standoff with no way out. Resolving this conflict is, alas, far beyond the scope of this article (and not likely possible). But, in addition to noting its existence as an effective instrument of backlash in the gender culture wars, ${ }^{100}$ I offer two observations. First, as the $\mathrm{CNN}$ forfeiture story shows, it is all too easy for any position one might take against gender equality to be elevated to the level of "religion" and clothed

97 Longman, supra note 3, at D1 (internal quotation marks omitted).

98 Id. (internal quotation marks omitted).

99 See, e.g., Garner, supra note 66 (statement of one coach who was critical of the forfeiture) ("[T]his girl qualified for the states so she must be tough. He should have wrestled her.") But the coach's criticism was neutralized once religion was introduced into the article: "Smith could see a male wrestler electing not to wrestle a female based on religion. 'If there was no situation like religion, I'd tell him to get his butt on the mat and wrestle because she's worked just as hard as he has.' "Id.

100 If anything, such clashes seem to be arising with increasing frequency-as highlighted by the recent flare-ups surrounding access to contraception versus the liberty of religious institutions in the campaign for the Republican presidential nomination. See, e.g., Stephanie Condon, Romney Continues Republican Line of Attack on Obama over "Religious Liberty," CBS News (Feb. 6, 2012, 2:47 PM), http://www.cbsnews.com/8301-503544_162-57372043 -503544/romney-continues-republican-line-of-attack-on-obama-over-religious-liberty/. 
with the legitimacy that label affords. If inegalitarian norms themselves wear the mantle of religion, gender equality will always be stymied by framing the opposition to it in religious terms. In the Iowa forfeiture controversy, the existence and legitimacy of the religion side of the conflict was accepted without any scrutiny of whether the forfeiture decision was actually required by the tenets of the family's religion, or whether there might be room for differently interpreting their religious commitments to avoid a conflict. Some Catholic schools, for example, have allowed their male wrestlers to wrestle girls, but at least one wrestling coach at a Catholic school has taken a strong stance against forfeiting matches to girls. ${ }^{101}$ The religious concern articulated by Joel is that his religion requires him to respect girls and that wrestling girls would amount to disrespecting them. But, is wrestling girls really disrespectful to them? This understanding does not comport with how girls themselves experience the alternatives of wrestling versus forfeiture. Female wrestlers often complain about forfeitures, even ones purportedly motivated by religious reasons. ${ }^{102}$ The underpinnings of the presumed religious conflict are murky at best. As one wrestling coach who was critical of Northrup's forfeiture noted, "there's nothing in the Bible that states that you can't engage (a female) in athletic competition. He's not going out there to try to hurt her, he's just going out there trying to beat her." 103 This coach added, "I think he's being more disrespectful because he didn't want to wrestle her. She put in all that time to wrestle and then he doesn't want to wrestle her."104

In questioning the media's unreflective acceptance of religious conflicts when used to counterbalance gender equality claims, I am not arguing for imposing any kind of requirement for a textual grounding in order for a religious claim to be recognized as sincere. That would put too much of a premium on orthodox, conventional religious doctrine-and veer uncomfortably close to Establishment clause territory. Dean Martha Minow notes this concern when she argues against making the centrality of religious belief to the religion's official doctrine a litmus test for resolving such conflicts through law. ${ }^{105}$ Nor should textual support for a religious claim necessarily be taken at face value in these clashes. Interpretations of religious text do not exist independently of the social forces that give rise to political struggles over equality rights. Instead of treating these interpretations as fixed and set in stone, we should recognize that they too are a product of social relations.

What too often is lost in popular discourse pitting religion against gender equality is that religious interpretations are themselves a product of specific historical and cultural forces; they shift as culture and social relations change. Professor William Eskridge's review of the biblical support marshaled by supporters of slavery and apartheid offers a rich historical example of how inter-

101 See Thomas, supra note 33, at D1.

102 Patel, supra note 48, at 4 (reporting complaints of two female high school wrestlers about forfeitures and boys' "typical comments" of "It's against my religion," and "I don't want to hurt you.").

103 Garner, supra note 66 (emphasis added).

104 Id.

105 Martha Minow, Should Religious Groups Be Exempt from Civil Rights Laws?, 48 B.C. L. REV. 781, 827-29 (2007). 
pretations of religious texts change along with social understandings. ${ }^{106} \mathrm{He}$ traces the history of clashes between religious belief and racial equality, which occurred frequently until the civil rights movement took hold and changed mainstream religious understanding of racial integration and interracial relationships. ${ }^{107}$ Today, we no longer see clashes between religion and racial equality, but religion clashes frequently with movements for gender and sexualorientation equality.

In negotiating conflicts between religion and equality, instead of treating religious opposition as fixed and absolute, a more productive approach would examine the possible alternative interpretations within a religious belief system that could avoid a head-on clash with equality norms. Even within a particular religion, beliefs about gender and equality are not monolithic, forever fixed in time. Professor Eskridge demonstrates this in highlighting the rifts within religions, denominations, and churches on issues of LGBT equality. Analogizing to similar shifts with respect to racial equality, he shows how religious beliefs themselves reflect societal changes in commitments to equality. ${ }^{108}$ Conflicts between religion and equality may seem less intractable and absolute when the plurality of religious views on the subject is brought to light. ${ }^{109}$ This might have been done in the forfeiture context by highlighting alternative interpretations of that same religious tenet, to respect women, that would have allowed the match to take place.

My second observation is that it is not productive to consider such a clash of values at an abstract level of religious belief versus gender equality. When such clashes arise, they occur in specific settings, and the norms and values of the societal institutions in which they occur should inform their resolution. ${ }^{110}$ The forfeiture here took place in a public school setting. ${ }^{111}$ This is an institutional setting with a great deal of experience in sorting out clashes between accommodating religious practices and conformity with public school values, including protecting equal opportunity. ${ }^{112}$ If, for example, a male student in a public school believed that he could not take instruction from a female teacher

106 See William N. Eskridge, Jr., Noah's Curse: How Religion Often Conflates Status, Belief, and Conduct to Resist Antidiscrimination Norms, 45 GA. L. Rev. 657, 666-68 (2011).

107 Id. at 665.

$108 I d$. at 666-68.

109 See, e.g., Madhavi Sunder, Piercing the Veil, 112 YALE L.J. 1399, 1401 (2003) (discussing Muslim women's engagement with religious doctrine while asserting claims of human rights and women's rights).

110 For an argument using the institutional norms of the setting in which a similar clash of foundational norms arises to work through conscience-based refusals to provide contraception, see Jill Morrison \& Micole Allekotte, Duty First: Towards Patient-Centered Care and Limitations on the Right to Refuse for Moral, Religious or Ethical Reasons, 9 AvE MARIA L. REv. 141, 146-48, 167-70 (2010).

111 Although Joel was home-schooled, he chose to affiliate with, and participate on, a public school team. See Meredith, supra note 3, at A1 (noting that Joel Northup is homeschooled).

112 For the Supreme Court's latest foray into clashes between religion and equality in an educational (albeit university) setting, see Christian Legal Soc'y v. Martinez, 130 S. Ct. 2971, 2980, 2995 (2010) (upholding state university's nondiscrimination policy as applied to Christian student organization that sought to exclude "unrepentant homosexual[s]" from membership while still retaining the benefits of a school-sponsored student organization). 
or could not sit in the same classroom as a girl for religious reasons, gender equality norms would clearly prevail over the student's religious objections. As a matter of statutory law, the conflict between religious liberty and gender equality in education has been worked out by giving religious schools an exemption from the gender nondiscrimination mandate that otherwise applies to federally-funded schools. ${ }^{113}$ When such conflicts arise within institutions that are within the public realm and governed by nondiscrimination law, equality norms typically take precedence over religious objections, requiring objectors to forego the benefits of public institutions if their requirements conflict with religious belief. ${ }^{114}$ While there may be a variety of possibilities for resolving specific clashes between religion and equality, the main point here is that leaving such clashes at the abstract level of religion versus equality ignores the importance of context and institutional norms, and makes the conflict look more intractable, and more like a stalemate, than it need be.

In practical terms, the way these conflicts get sorted out does not depend on a principled weighing of the values as much as the social and historical forces that prevail at any given time. As Dean Martha Minow has explained, the contrasting treatment of race, gender, and sexual orientation in clashes with religious opposition turns on differences in our collective commitment to end each type of discrimination and the extent to which there remain lingering doubts and ambivalence about these equality projects. ${ }^{115}$ Law, social norms, and religious beliefs all interact and mutually constitute one another. ${ }^{116}$ Just as the conflict does not exist at the level of abstract principles, neither does it exist apart from social struggles over gender roles.

While this analysis suggests that the key to overcoming religious opposition is to press forward with equality claims in order to change social understandings of gender, such an effort does entail risks. Dean Minow cautions that refusals to accommodate religious beliefs in such clashes can produce martyrs, trigger backlash, and drive religious persons out of the institutions of civil society, ultimately weakening support for equality rights. These risks are real and worthy of consideration. But, as Professor Eskridge shows in his historical analysis of biblical clashes with racial equality, the relationship between religion and equality is a dynamic one and religious opposition may shift as equality

113 See 20 U.S.C. $\$ 1681(a)(3)$ (2012) (“[T]his section shall not apply to an educational institution which is controlled by a religious organization if the application of this subsection would not be consistent with the religious tenets of such organization."). In addition, the Supreme Court has interpreted the First Amendment to require an exemption from antidiscrimination laws that would otherwise intrude into relationships between churches and their ministers, including an employment relationship between a teacher and a religious school operated by a church. See Hosanna-Tabor Evangelical Lutheran Church \& Sch. v. EEOC, 132 S. Ct. 694, 706-08 (2012).

114 Cf. Linda C. McClain, Religious and Political Virtues and Values in Congruence or Conflict?: On Smith, Bob Jones University, and Christian Legal Society, 32 CARdozo L. REv. 1959, 1959-60 (2011) (discussing our Nation's conflicting foundational views on the relationship between civil society_including the family and religion-and the state, and differentiating between forcing compliance with state democratic norms, which should be disfavored, and withholding state benefits for noncompliance with such norms, which fits more comfortably in a pluralistic state).

115 See Minow, supra note 105, at 845-46.

116 Id. at 846; see also Eskridge, supra note 106, at 712. 
commitments grow. Exposing the plurality of religious views regarding gender equality can help bring this about, as can greater attention to the institutional setting in which these clashes occur. Moreover, if the norms of masculinity expand to embrace those boys who wrestle girls, so that boys can find a culturally valued masculinity whether they win or lose, wrestling girls may come to be seen as consistent with respecting them, and thus consistent with religious views about respecting women.

\section{Asymmetrical Agency}

A second undercurrent in the story of the Iowa forfeiture pits the questionable agency of the young woman in her desire to wrestle against the presumptively complete agency of the young man in his decision to forfeit. He appears as decisive and resolute, while her decision to wrestle is treated as more circumspect.

For all social actors, there is both agency and constraint; everyone acts within a range of choices defined and shaped by external influences. Feminist legal scholar Kathy Abrams calls this "partial agency." 117 But a more simple narrative emerges in the media telling of the Iowa forfeiture story: in forfeiting, Joel Northrup made a bold decision, at some sacrifice to his own interests, based on his own authentic values. Not only does the narration expressly dispel any suggestion that he acted at his father's behest-despite his father looming in the background-it reaffirms the integrity of the internal value system that prompted his actions. Cassy's agency comes off as more questionable; with the disparagement of mixed-sex wrestling, the viewer is left to wonder why she wants to wrestle in the first place and whether it is really the best thing for her. There is no effort to explain or authenticate her decision to wrestle. This is consistent with other media coverage of female wrestlers, which puts female wrestlers in the position of having to explain and justify their desire to wrestle. For example, in an episode of HBO's Real Sports, Bryant Gumbel questioned whether a female wrestler would "grow out of it." 118 Reactions to the media coverage generated a lot of comments along the lines of, "what kind of girls would wrestle?" taking the cue from the storyline that wrestling for girls may not be an authentic or creditable choice. ${ }^{119}$

The asymmetrical agency implicit in the CNN story-elevating the agency of the person resisting subversive understandings of gender while questioning the agency of the challenger-is a species of what law professor Jill Hasday calls a "mutual benefits argument." ${ }^{120}$ In a recent article, Professor Hasday demonstrates that mutual benefits arguments-arguments that the real best interests of the subordinated group are aligned with proponents of the status quo-have persistently played a role in opposition to racial and gender equality claims. She shows that such arguments are endemic to struggles over racial and gender equality throughout American history dating back to defenses

117 Kathryn Abrams, Sex Wars Redux: Agency and Coercion in Feminist Legal Theory, 95 Colum. L. Rev. 304, 306-07 (1995).

118 Walton, supra note 14 , at 65.

119 Preece, supra note 5; see also Nakashima, supra note 64, at A1.

120 Jill Elaine Hasday, Protecting Them from Themselves: The Persistence of Mutual Benefits Arguments for Sex and Race Inequality, 84 N.Y.U. L. Rev. 1464, 1465-86 (2009). 
of slavery and opposition to women's suffrage and showing up more recently in challenges to affirmative action (in allegations that it stigmatizes beneficiaries) and in opposition to abortion rights (reflected in claims that women regret abortions and are harmed by them). ${ }^{121}$ By asserting that the true interests of subordinated groups would not be well served by equality claims, these arguments enable decision makers to minimize the appearance of social conflict and seemingly avoid taking sides in a struggle between competing meanings of equality.

A similar kind of mutual benefits argument is operating in the subtext of the Iowa forfeiture controversy. The decision to forfeit is portrayed as resting on the view that fighting women is against their true interests and that protecting women from male violence-even in the wrestling ring - is for their own good. The implicit message is that female wrestlers need to be protected from their decision to wrestle men. In the CNN story, Joel Northrup is depicted as thoughtful, decisive, and acting for the best interests of women, in contrast to Cassy Herkleman, who acts for unknown (and less understood) motives, perhaps impulsively or at the behest of others.

As Hasday details, equality claims often falter-or are at least slowed down -in the face of mutual benefits arguments. ${ }^{122}$ Part of their appeal is that they resonate with deeply ingrained perceptions of the marginal agency of the members of subordinated groups. The person asserting equality rights is cast as unreliable in charting her or his best interests. Hasday persuasively argues that mutual benefits claims should be treated with suspicion given their historic function and their reliance on stereotypes about the compromised agency of women and people of color-stereotypes that are in tension with the normative commitments of equality law. ${ }^{123}$

Here too, the contrasting agency of the forfeiter and the female wrestler functions to solidify the very understandings of gender that have kept women out of the ring. Importantly, it deflects attention from the social and institutional forces that may have influenced the forfeiture decision and constrained the boy's agency. Given the power coaches have over athletes, and their extraordinary influence in shaping athletes' values and choices, it is likely that the views of Joel's coach played at least some role in his decision to forfeit. A coach would likely hold great sway in either encouraging a decision to forfeit or forbidding it. ${ }^{124}$ On the other hand, a girl's decision to wrestle takes a remarkable amount of decisiveness and self-direction-and a great deal of fortitude to resist cultural expectations and negative popular images of female wrestlers. ${ }^{25}$ By overstating his agency and downplaying hers, the forfeiture

121 Id. at 1465, 1478; see also Reva B. Siegel, Dignity and the Politics of Protection: Abortion Restrictions under Casey/Carhart, 117 YALE L.J. 1694, 1698-99 (2008) (discussing the regret thesis in the anti-abortion argument).

122 Hasday, supra note 120, at 1495-96.

123 Id.

124 See, e.g., Gregory Kane, Win or Lose, Girl Wrestler Shows Great Skill, BALt. Sun, Mar. 7, 2007, at 1B (describing a male wrestler's forfeit to a girl as the coach's decision).

125 See, e.g., Macro, Viveiros, \& Cipriano, supra note 37, at 51 (highlighting female wrestlers' agency in resisting popular images of wrestling, and explaining that the female wrestlers in the study viewed wrestling as an appropriate sport for them, even though they acknowledged that the general public views it as a masculine sport); id. at 43 (discussing sport as a vehicle for women to experience agency and empowerment). 
looks like a product of choice, and not a product of (or agent of) gender inequality itself. The role of normative masculinity-what it means to be a manis hidden, both in terms of how it shapes the forfeiture decision, and how it is, in turn, produced by the forfeiture decision. The forfeiture decision appears to be a product of choice instead of a product of (and a contributor to) inequality.

\section{Leveling Down and the Appearance of Neutrality}

A third aspect of the Iowa incident that operates to solidify the gender status quo is what I have previously discussed as the phenomenon of leveling down in response to equality claims. ${ }^{126}$ The forfeiture is a response to what is, effectively, a claim for equal inclusion. Cassy's attempt to wrestle in the state championship, an event historically limited to men, is an assertion of women's right to be treated as equals in sport. Joel's decision to opt out of the match rather than wrestle her is essentially a leveling down move: rather than wrestle her as an equal, he will deprive himself, along with her, of the match. It is a classic leveling down response to an equality claim-both wrestlers lose the opportunity to wrestle.

As I argued in an earlier article, leveling down is an effective strategy for resisting assertions of equality because it preserves existing social meaningsin this case, traditional understandings of gender-while eluding the censure of legal and moral proscriptions against discrimination. ${ }^{127}$ Leveling down responses like this one function to solidify status-based hierarchies and reinforce cultural messages about the inferiority of the subordinated group. Indeed, forfeiture is only one example of leveling down as a strategy to oppose girls' entry into wrestling. Several years ago, the Texas Wrestling Officials Association decided to disband rather than officiate coed matches. ${ }^{128}$ As one official explained, "if girls wrestle, they'll embarrass the boys. They'll detract from the accomplishments the boys have worked so hard to attain." 129 Texas ultimately set up a separate championship for girls to avoid this spectacle. ${ }^{130}$ Nor is the strategy of leveling down limited to sex equality claims in the context of wrestling, or even sport in general. In one of the most notorious historical examples of leveling down, the city of Jackson, Mississippi sent a powerful message of racial stigma and inferiority by closing its public swimming pools rather than integrating them in response to a lawsuit brought by African American residents challenging their racially segregated operation. ${ }^{131}$ Leveling down can be a potent way of enforcing a group's second-class status by revealing the depth of negative feelings behind the community's judgment of stigma. The message sent goes something like this: we (the dominant group) feel so

126 See Deborah L. Brake, When Equality Leaves Everyone Worse Off: The Problem of Leveling Down in Equality Law, 46 WM. \& MARY L. Rev. 513, 515 (2004).

$127 \mathrm{Id}$. at 517.

128 Walton, supra note 14, at 57 (stating that in 1996, the Texas Wrestling Officials Association refused to provide referees to officiate boy-girl wrestling matches); see also Texas Wrestling Groups Say No to Boy-Girl Grappling, N.Y. Times, Dec. 30, 1996, at A9.

129 Walton, supra note 14, at 57.

130 Id.

131 See Palmer v. Thompson, 403 U.S. 217, 218-19 (1971) (rejecting an equal protection challenge to the closure of the city's public swimming pools); see also Brake, supra note 126 , at 518-20 (discussing this case). 
strongly about keeping you (the subordinated group) out of our pools that we would rather deprive ourselves of this benefit than share it with you. Likewise, the forfeiture decision was all the more powerful as a stigmatizing agent because of its tangible cost to Joel: the message that girls should not wrestle boys was underscored by Joel's willingness to sacrifice his own chances of winning the tournament.

Precisely because of the cost inflicted on dominant group members, leveling down can be an especially effective strategy for preserving subordination as compared to discrimination that takes the form of differential treatment. And yet, discrimination law typically does not recognize leveling down as a form of actionable discrimination. ${ }^{132}$ Moreover, since the equality claimant is not treated any worse than the dominant group member (on the surface, at least), the leveling down action does not usually generate the kind of moral condemnation that more overt discrimination is likely to produce. A rule barring girls from wrestling matches would be recognized as discriminatory and prompt a debate about gender equality in sport. But, a forfeiture-and even a pattern of forfeitures with the same effect as a ban-is much less likely to be viewed as discriminatory or start a dialogue about girls' lack of equal opportunity in the sport.

As a leveling-down strategy, the forfeiture decision appeared neutral in its applicability to Joel and Cassy: neither of them wrestled. In this guise, the underlying opposition to girls' wrestling did not lend itself to, nor did it produce, a discussion on CNN of how such forfeitures block girls' opportunities in the sport, or an inquiry into the gender ideology behind the forfeiture and its connection to gender inequality in sport. Leveling-down responses take advantage of the prominence of the formal equality model in law and popular consciousness, and the prevailing understanding that formally sex-neutral rules are all that equality demands. The forfeiture also maps onto strongly liberal dichotomies of the public/private and the active/passive. The forfeiture is viewed as the private decision of Joel, not attributable to the school; and the decision is seen as a refusal to act, not an affirmative act of interfering with girls' opportunities to wrestle. The forfeiture decision thus largely escapes scrutiny for its role in thwarting gender equality.

\section{The Strategic Appropriation of Feminism}

A final way that the forfeiture story solidifies traditional understandings of gender is through the strategic appropriation of de-contextualized strands of feminist theory. Consistent with Reva Siegel's theory of "preservation through transformation," feminist ideologies of gender can be co-opted in service of the status quo of gender hierarchy. ${ }^{133}$ As insights from feminist theory work their way into the popular consciousness and become mainstreamed, they can lose their subversive force and be redirected to resist threats to the gender order. In

132 Brake, supra note 126 , at 522.

133 See Reva Siegel, Why Equal Protection No Longer Protects: The Evolving Forms of Status-Enforcing State Action, 49 Stan. L. Rev. 1111, 1113 (1997); see also Reva B. Siegel, "The Rule of Love": Wife Beating as Prerogative and Privacy, 105 Yale L.J. 2117, 2119 (1996) [hereinafter Siegel, 1996]. 
the Iowa forfeiture drama, each of three major schools of feminist legal theory was used to erase the transformative potential of girls wrestling with boys.

Most prominently, the main theme that emerges in the CNN story resonates with dominance feminism's call to end violence against women. ${ }^{134}$ Coed wrestling is depicted as sending the message that it is okay for men to hit and hurt women, with no attention to the very different contexts of the wrestling ring versus the home, the street, or the workplace. The persuasive force that dominance feminism has had on American culture, as evidenced in movements like "Take Back the Night" and campaigns to end domestic violence, is marshaled to assign to Northrup the role of protector of women, with the girls who wrestle cast in the role of potential victims and the boys who wrestle them, implicitly, their potential abusers. The attack on coed wrestling thus gains part of its cultural power from the very success of the feminist campaign to end violence against women.

Northrup's explanation of his decision in terms of "respect" for women resonates in a way that makes it harder for feminist critique to pierce. This is a common "move" in resisting girls' entry into wrestling. Many news articles that report on resistance to girls in wrestling repeat this theme, as exemplified in one newspaper article reporting the opinion that coed wrestling is "rightly condemned by anyone who respects the rights and dignity of women."135 At the same time, protecting girls from violence in the sport is wrapped up in protecting the girls' virtue from sexualized groping. As one high school boy identified as attending a Christian school explained to a reporter, "I've always been told that you have to have respect for women. The nature of the sport goes against what I've been taught . . . . It's different than football. There you're separated by pads, not a thin layer of Spandex." 136 In a similar coupling of sexuality and violence, a male wrestling coach explained that he would never demonstrate a wrestling move on a girl out of fear of prompting a sexual harassment complaint. ${ }^{137}$ This same article reported an incident in which a boy wrestling a girl was jeered with taunts of "Sexual harassment!" and "Rape!" by male spectators. ${ }^{138}$

The cultural traction of dominance feminism is, thereby, used to fuel a rallying cry for defending social arrangements that keep girls and women in traditional roles. The male wrestler who forfeits becomes a pseudo-feminist hero for refusing to participate in the sexual and violent denigration of girls and women that dominance feminism has exposed as central to women's inequality. In effect, it is a "hoist them on their own petard" kind of move, using one school of feminism to justify depriving women of opportunities that could empower them-a result that undermines the very feminist ideology being appropriated. ${ }^{139}$

134 See generally Martha Chamallas, Introduction to Feminist Legal Theory 44-53 (2d ed. 2003) (discussing dominance feminism and its impact).

135 Walton, supra note 14, at 57-58.

136 Brunswick, supra note 62, at 1B (internal quotation marks omitted).

137 Nakashima, supra note 64, at A1.

138 Id.

$139 C f$. Juliet A. Williams, Doing Difference, in Feminism, Masculinities, and the Law (Martha Fineman \& Michael Thomson eds., Ashgate Press, forthcoming) (on file with 
Less obviously, cultural feminism is also invoked and exploited to resist the threat posed by girls wrestling boys. In cultural feminism, women's distinctive attributes and experiences are highlighted and used as a basis for critiquing and refashioning rules and institutions that are skewed male so that they better fit women. ${ }^{140}$ This effort often leads to the identification of gender "difference" and discussions of what to do about it. In the wrestling controversy, reference is made to gender difference as a justification for separating girls' and boys' wrestling. Opponents of coed wrestling invoke feminist calls for the recognition of gender difference when they urge separate wrestling competitions for girls to respond to their needs and interests in the sport. Running throughout the media coverage in Iowa and other stories about girls wrestling is the claim by opponents, couched in the language of a cultural feminist approach to equality, that girls deserve their own wrestling teams and competitions. This claim is even invoked by the supporters of girls wrestling boys, effectively apologizing for their position by explaining that the girls had no alternative because they had no separate event of their own. The asserted need for girls-only competition is supported with references to gender difference, including that girls wrestle differently, relying more on technique than strength. ${ }^{141}$ By claiming that girls should have separate wrestling events, opponents are able to push back against coed wrestling while deflecting charges of sexism, since their claim resonates with a kind of feminism that has infiltrated popular culture (as in, women's distinctive styles of leadership, judging, etc.), while exploiting this strand of feminism to the ends of solidifying male power in sport. The threat to the gender order posed by coed wrestling is also diluted, since supporters make their case by apologizing for girls' entry into the sport, suggesting that girls are only legitimately there because they lack their own teams.

Finally, in the discourse surrounding girls in wrestling, liberal feminism, too, is appropriated in service of protecting traditional understandings of gender. The most anemic form of liberal feminism, gender-blind formal equality, is reflected in comments that "explain away" girls' successes in the sport by portraying the girls as having given up any claims to girlhood, rendering them exceptional and aberrational, just like "one of the boys." 142 A common refrain in media coverage of girls in wrestling is to highlight the girl's exceptionalism with comments proclaiming that she is not regarded as a girl at all, but just another wrestler. ${ }^{143}$ As the male coach of the girl who won Vermont's wres-

author) (discussing the strategic appropriation of feminist discourses on intersectional identity to bolster the politics of a "boy crisis" and re-entrench essentialist gender ideals in debates over single-sex education).

140 See Chamallas, supra note 134, at 57-60 (discussing cultural feminism).

141 Weisberg, supra note 53, at N12 (statement of coach of female wrestler) ("Lisa wins with technique over stronger boys."); $i d$. (statement of female wrestler) ("I've had to work twice as hard to be tough, and to prove myself. There are no special breaks for women. In fact, the top female wrestlers have better technique than the best males because it's what they have to rely on more than strength."); Kane, supra note 124 (reporting comments that women wrestle differently, "more technically proficient," than men and boys).

142 See Chamallas, supra note 134, at 16-17 (discussing liberal feminism).

143 Weisberg, supra note 53, at N12 (statement of coach of a female high school wrestler) ("We regard her as a wrestler first, not as a female."). The same coach used this wrestler's exceptionalism to distance her from other, less-accepted girls: "She's the only girl on the 
tling championship said of her, "she's a great kid. I see her as a wrestler, not a female." 144 Instead of subverting gender relations, girls' presence in the sport is reframed as consistent with gender hierarchy, because she is not "really" a girl.

Oddly, the gender-blind narrative ("she's not a girl, she's a wrestler") coexists with the gender-special narrative (girls wrestle differently, girls deserve their own meets) within the same discussions and articles, even by the same persons. The inconsistency is not acknowledged, perhaps because both claims resonate with the distorted ways that feminist commitments get mediated by mainstream culture. For liberal feminism, the mainstreamed message is: be gender blind, gender does not matter (as in, these are just wrestlers, not girls). ${ }^{145}$ For cultural feminism, the received message is one of gender difference, and the need to accommodate it (as in, girls should have their own wrestling matches separate from boys). ${ }^{146}$ In both iterations, the subversive impact is lost and the discourse has the outward appearance of being consistent with a pro-gender-equality agenda, even as the messages operate to solidify traditional understandings of gender. In this way, multiple strands of feminist theory are lifted out of context, oversimplified, and deployed in defense of patriarchal gender norms. Feminist theory, filtered through a pop culture lens, becomes an instrument for defending the gender order under threat from the entry of girls into the sport. ${ }^{147}$

Together, these four moves coalesced to tell a story in Iowa that thwarted the potentially subversive threat to the gender order presented when girls and boys compete against one another in competitive wrestling. The next Section pauses to consider whether sex equality law, specifically Title IX and the Equal Protection Clause, is violated by schools' acquiescence in sex-based forfeitures such as the celebrated one in Iowa. It concludes that, despite some doctrinal hurdles, a persuasive argument can be made that schools and athletic associations have a legal obligation to take reasonable steps to discourage and prevent sex-based forfeitures that limit girls' and women's competitive opportunities in the sport.

team right now. ... We've had girls in the past, but they came out mostly for the attention. Lisa has always been there for the sport." Id.; see also Parker, supra note 36, at D1 (statement of male teammate of a female wrestler on the team's pact not to date her) ("More than anything, it's a sign of respect .... She's equal. She's one of the boys now.").

${ }^{144}$ Longman, supra note 3, at D1.

145 See Chamallas, supra note 134, at 17.

146 See id. at 56.

147 The recent dust-up over Rush Limbaugh's attack on a Georgetown law student for her efforts fighting for insurance coverage of contraceptives is indicative of how crucial the appropriation of feminist-sounding rhetoric has become in an effective backlash. Limbaugh's attack, calling the young woman a "slut" and "prostitute," fell flat; his criticism took the form of overtly retro-sexist language, without any reference to or appropriation of feminist-sounding slogans. The attack backfired. See Maggie Fazeli Fard, Sandra Fluke, Georgetown Student Called a "Slut" by Rush Limbaugh, Speaks Out, WAsh. Post (Mar. 2, 2012, 11:06 AM), http://www.washingtonpost.com/blogs/the-buzz/post/rush-limbaugh-callsgeorgetown-student-sandra-fluke-a-slut-for-advocating-contraception/2012/03/02/gIQAvjfS $\mathrm{mR}$ _blog.html. Thanks to my colleague Jules Lobel for raising this example in our conversation about appropriating feminism in service of a backlash. 


\section{A Look at the Law: Does Sex-Based Forfeiture Violate Sex Discrimination Law?}

Law relates to the phenomenon of gender-based forfeiture in two ways: it sets the background rules that shape the environment in which forfeitures occur, and it provides a potential constraint on such forfeitures by regulating how school officials respond to them. This Section primarily emphasizes the second relation, crafting an argument that school acquiescence in gender-based forfeitures may violate discrimination law. This argument has several doctrinal hurdles to clear but does not require a radical reinterpretation of existing law or an unusually creative reading of precedent.

Starting with the legal building blocks, the core statutory provision of Title IX is largely an open slate, forbidding recipients of federal funding from discriminating on the basis of sex. ${ }^{148}$ It leaves open the critical question of what it means to discriminate based on a person's sex. The statute says nothing about athletics specifically or what sex discrimination means in that particular setting, much less anything about the specific issue of male students refusing to compete against girls. Questions about the statute's coverage of athletic programs, and many of the details about how the law applies to athletics, were settled by a series of regulations and interpretations issued by the federal enforcing agency. ${ }^{149}$ The starting point is the 1975 regulations, promulgated with express authority from Congress, which detail certain requirements for providing equal opportunity in athletics. ${ }^{150}$ Several provisions in these regulations are relevant here.

First, the regulations permit schools to offer separate-sex teams if team selection is based on competitive skill or the sport in question is a contact sport. ${ }^{151}$ This provision effectively permits all varsity sports to be segregated by sex because varsity sports typically are selective. However, even if that were not the case, the regulation would still permit wrestling to be single-sex, since it is undoubtedly a contact sport, which is also a justification for offering separate-sex teams. Although the regulation grants a limited set of integration rights when teams are offered on a separate-sex basis-that is, granting a right to try out to members of the excluded sex-such rights are not available to female athletes who go out for wrestling. The same regulation that permits sex-separation also grants members of the excluded sex the right to try out for a team offered only to members of the other sex, but only if athletic opportunities for the excluded sex have been previously limited, and only if the sport in question is not a contact sport. ${ }^{152}$ Since wrestling is a contact sport, this right is not available to female athletes who want to wrestle, even if they can demonstrate

14820 U.S.C. $\$ 1681$ (2012) ("No person in the United States shall, on the basis of sex, be excluded from participation in, be denied the benefits of, or be subjected to discrimination under any education program or activity receiving Federal financial assistance . . ..”).

149 Originally, that was the former Department of Health, Education and Welfare; that authority was subsequently assumed by the Department of Education when it took over in 1980. See Cohen v. Brown Univ., 101 F.3d 155, 165 n.5 (1st Cir. 1996) (explaining this history).

150 See id. at 165 (describing the authority for the athletics regulations).

15134 C.F.R. $\S 106.41($ b) (2011).

152 Id. 
that their athletic opportunities have been limited. This provision, known as the contact sports exemption, has been widely criticized by legal scholars, but it has remained in force ever since the regulation was promulgated in $1975 .{ }^{153}$ As a result, if a girl wants to participate in wrestling and the school offers wrestling only to boys, Title IX does not give her the right to try out for the boys' team.

Despite the contact sports exemption, there is one other chance for girls to use Title IX to gain opportunities to wrestle. Where a school offers a boys' team in a sport, but no girls' team in that sport, Title IX may provide a right to a separate girls' team in that sport. ${ }^{154}$ However, that right is limited to where there is already sufficient interest and ability at the school to support the new girls' team and a reasonable opportunity for competition for that team in the school's normal competitive region. ${ }^{155}$ The chicken-and-egg problem with this requirement is apparent. Without opportunities to practice and compete, the interest and ability to support the team will not likely exist, nor will competition likely exist in the competitive region until a critical mass of schools offer girls' teams in the sport. ${ }^{156}$ Despite the obvious circularity, these requirements are a prerequisite to using Title IX to require a school to add a girls' team in a sport only offered to boys. As a result, Title IX has rarely, if ever, required a school to add a girls' wrestling team based on the school's offering of wrestling to boys. Between the contact sport exception and the high hurdle to force a school to add girls' wrestling, Title IX has been of little help in getting girls access to the sport of wrestling.

However, Title IX is not the end of the line for an aspiring female wrestler. Public schools are bound by the equal protection clause in addition to Title IX, and it includes no exception for contact sports. Precedents in the lower courts dating back to the 1970s have applied the equal protection clause to forbid public schools and state athletic associations from denying girls an equal right to participate in a sport offered only to boys, even in contact sports. ${ }^{157}$ Wrestling, in particular, has been the subject of equal protection litigation, and lower courts have upheld girls' rights to try out for boys' teams in sports not offered to girls. ${ }^{158}$ Today, even many private schools, which are not bound by

153 See, e.g., BRAKE, supra note 18, at 44-48, 64 (critiquing the contact sports exception); Suzanne Sangree, Title IX and the Contact Sports Exemption: Gender Stereotypes in a Civil Rights Statute, 32 Conn. L. Rev. 381, 449 (2000).

154 The 1979 Policy Interpretation issued by The Department of Health, Education, and Welfare ("HEW") provides that

[I]f an institution sponsors a team for members of one sex in a contact sport, it must do so for members of the other sex under the following circumstances:

(1) The opportunities for members of the excluded sex have historically been limited; and

(2) There is sufficient interest and ability among the members of the excluded sex to sustain a viable team and a reasonable expectation of intercollegiate competition for that team. Title IX of the Education Amendments of 1972; a Policy Interpretation; Title IX and Intercollegiate Athletics, 44 Fed. Reg. 71,413, 71,418 (Dec. 11, 1979) (codified at 45 C.F.R. $\S 86.41$ (2007)).

155 Id.

156 For criticism of this standard, see BRAKE, supra note 18, at 105-106, 109-110.

157 For a history of this litigation and citations to the early cases, see $i d$. at 48-50.

158 See, e.g., Barnett v. Texas Wrestling Ass'n., 16 F. Supp. 2d 690, 696 (N.D. Tex. 1998); Adams v. Baker, 919 F. Supp. 1496, 1504-05 (D. Kan. 1996). 
the equal protection clause, voluntarily permit girls to try out for the wrestling team. $^{159}$

Despite Title IX then, girls generally do have access to male wrestling teams, at least where they do not have their own team in the sport. ${ }^{160}$ The next question is whether, once on the team, sex-based forfeitures violate girls' rights to nondiscrimination. Here, Title IX is of more consequence. Even though Title IX does not give girls the right to get onto a boys' wrestling team in the first instance, once on the team, it does protect them from sex-based discrimination and the denial of equal athletic opportunity. The key case establishing Title IX's applicability to contact sports under such circumstances is Mercer v. Duke University. ${ }^{161}$

In that case, the football coach at Duke University (a private school, and not a state actor for equal protection purposes) announced that Heather Sue Mercer was a member of the football team after Mercer, a former place kicker for her high school football team, kicked the winning field goal in an intrasquad off-season scrimmage game. Prior to that celebrated goal, as an incoming freshman, Mercer had tried out for the team as a walk-on place kicker. Although she did not make the team in the try-out, she was allowed to serve as a team manager and regularly attended practices and participated in winter and spring conditioning drills during her freshman year. ${ }^{162}$ That spring, the seniors on the team selected Mercer to play in the scrimmage game. ${ }^{163}$ Mercer's winning kick was televised on ESPN and the coach publicly announced to the news media and to Mercer that she was on the team, amid a flurry of media attention. ${ }^{164}$

Soon afterwards, however, the coach seemed to have a change of heart. In her complaint filed in federal court, Mercer alleged that the coach belittled her with sexist comments and refused her playing time because she was female. ${ }^{165}$ Mercer cited as examples comments to the effect that she should have gotten

159 See, e.g., 2010-2011 CIF/NFHS Athletic Participation Census, CAl. InTERscholastic FED'N (2011), https://www.yousendit.com/download/T2dkeFVYTmEwZ21VQU1UQw (citing eight private schools in California with females on the wrestling team); see also Varsity Wrestling, Chase Collegiate School, http://www.chasecollegiate.org/page.cfm?p=2735 \&teamID=21\&display=Roster (last visited Mar. 6, 2013) (listing at least two girls on its varsity wrestling team roster).

160 Equal protection rights to try out for a sport offered to the other team have not been extended to sports in which girls have been offered their own team. See BRAKE, supra note 18 , at $50-54$.

161 Mercer v. Duke Univ., 190 F.3d 643, 648 (4th Cir. 1999) (holding that once Mercer joined the football team, Title IX protected her); Mercer v. Duke Univ., 181 F. Supp. 2d 525, 535, 553 (M.D.N.C. 2001) (jury found for Mercer and awarded her \$1 in nominal damages, $\$ 2$ million in punitive damages, and attorney fees), vacated in part, $50 \mathrm{~F}$. App'x 643, 644 (4th Cir. 2002) (holding that punitive damages are not available in private actions under Title IX), aff'd in part, 401 F.3d 199, 212 (4th Cir. 2005) (upholding award of attorney fees). 162 Mercer, 181 F. Supp. 2d at 530. However, it is not clear that this try-out was itself nondiscriminatory. The coach himself, dressed in a suit and tie, conducted the try-out along with an assistant coach, and admitted at trial that the conditions for kicking were not ideal. Moreover, the coach had never before required a walk-on place kicker to try out for a place on the team. $I d$.

$163 I d$. at 530-31. In fact, Mercer was the first place kicker chosen. Id.

164 Mercer, 190 F.3d at 644-45.

165 Mercer, 181 F. Supp. 2d at 532. 
over wanting to play "little boys' games" a long time ago and that she should go out for beauty pageants and cheerleading instead. ${ }^{166}$ She also alleged that the coach singled her out and denied her opportunities to practice and develop her skills, ultimately forcing her off the team. ${ }^{167}$ During her sophomore year, according to Mercer, the coach treated her differently from other team members, refusing to let her participate in summer camp, dress for games, sit on the sidelines during games (saying she should sit in the stands "with her boyfriend") or participate in practices like the other walk-on team members. ${ }^{168}$ She alone was not issued equipment or a uniform. ${ }^{169}$ The coach effectively created a new status for Mercer as a non-active team member with a special set of restrictions. ${ }^{170}$ In the beginning of her junior year, the coach informed Mercer that she was no longer on the team and barred her from participating in conditioning drills, while allowing other, less-qualified walk-on kickers to remain on the team. ${ }^{171}$ Mercer was the first person the coach had ever dismissed from the team for an alleged lack of ability. ${ }^{172}$

The coach's growing hostility towards Mercer evidences the deep-seated but fragile (as in, socially constructed) connections between sport and masculinity. According to the trial court, the evidence showed that the coach became concerned that Mercer's presence on the team would have a negative effect on the players and on recruiting. ${ }^{173}$ His stated concerns revolved around the press attention generated by Mercer's presence and, particularly, an article in a Georgia newspaper making fun of the presence of a woman on the team. He worried that her presence "posed a threat to the psyche of the team" because of the "undue" publicity her presence generated. ${ }^{174}$ Implicitly, his concern linked the presence of a woman on the team to a potential decrease in status and accompanying loss of masculinity to the male players, who might be upstaged by a girl.

Mercer sued under Title IX for a denial of equal athletic opportunity. The district court dismissed the case on the ground that, since Title IX gave Mercer no right to participate in a men's contact sport in the first place, she had no right to any particular kind of treatment as a member of the team. ${ }^{175}$ The Fourth Circuit reversed, holding that once Mercer became a member of the team, the statute's general ban on sex discrimination, and the regulation's promise of equal athletic opportunity, protected her from sex discrimination. ${ }^{176}$ On remand, the case was tried before a jury. The jury sided with Mercer and awarded $\$ 1$ in compensatory damages and $\$ 2$ million in punitive damages. ${ }^{177}$

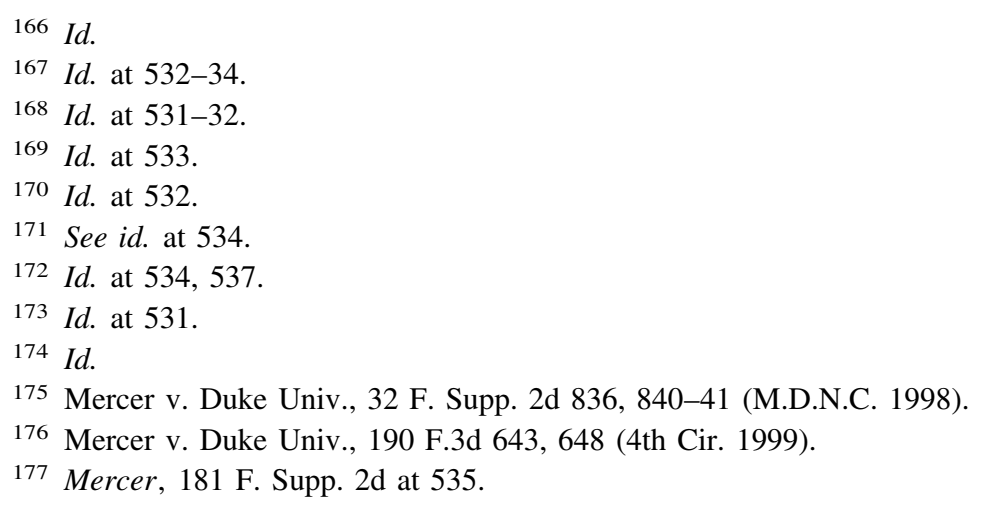


The award of punitive damages was later overturned by the Fourth Circuit in a ruling that Title IX does not authorize punitive damages. ${ }^{178}$

Applying Mercer to the forfeiture controversy in wrestling is a fairly straight-forward matter: although Title IX does not grant girls the right to try out for boys' wrestling teams, once on the team, girls have a right to equal athletic opportunity and freedom from sex discrimination. In fact, not just Title IX, but also the equal protection clause (for public schools) and any applicable state equal rights amendments and nondiscrimination statutes would bar sex discrimination against a female member of a school wrestling team. The issue then becomes whether an individual male wrestler's decision not to wrestle a girl amounts to sex discrimination that is attributable to the school-or, rather, whether a school's acquiescence in such gender-based forfeitures violates the school's obligations not to discriminate on the basis of sex.

The principle that schools could be liable under Title IX for their response, or lack thereof, to discrimination carried out by students was first established in a case involving sexual harassment, Davis v. Monroe County Board of Education. ${ }^{179}$ In that case, fifth grader LaShonda Davis experienced repeated sexually harassing behaviors from a male classmate over a period of five months with no meaningful intervention from the school district in response to the complaints of LaShonda's parents. The lower courts had exonerated the school district from any liability for what happened, concluding that Title IX does not make schools responsible for the discriminatory actions of their students. In a 5-4 decision, the Supreme Court reversed, holding that school districts may be held liable for damages under Title IX if they had actual notice of the harassment and responded with deliberate indifference. ${ }^{180}$ The Court further elaborated that, in order for student-to-student harassment to amount to actionable discrimination, it must be severe and pervasive enough that the victim is effectively denied access to an educational opportunity or benefit. ${ }^{181}$

This standard, requiring actual notice plus deliberate indifference, sets a high bar for holding schools liable and has been criticized for taking a lessprotective approach to students than the comparable federal law that governs sexual harassment in the workplace. ${ }^{182}$ However, it is not insurmountable. In many cases, the conduct of school officials is egregious enough that plaintiffs

178 Mercer v. Duke Univ., 50 F. App'x 643, 644 (4th Cir. 2002) (basing its ruling on a Supreme Court decision, Barnes v. Gorman, 536 U.S. 181 (2002) (holding that punitive damages are unavailable under Section 504 of the Rehabilitation Act which, like Title IX, was modeled on Title VI of the Civil Rights Act of 1964. Since those statutes, which proscribe disability discrimination and race discrimination in federally funded programs, did not authorize punitive damages awards, the Fourth Circuit reasoned, neither does Title IX)). Although the decision vacating punitive damages left Duke with a total damages payment of only one dollar (the award for compensatory damages), Duke was required to pay about $\$ 350,000$ in attorneys' fees. Mercer v. Duke Univ., 301 F. Supp. 2d 454, 470 (M.D.N.C. 2004), aff'd, 401 F.3d 199, 212 (4th Cir. 2005).

179 Davis v. Monroe Cnty. Bd. of Educ., 526 U.S. 629, 639 (1999).

180 Id. at $632-33$.

181 Id. at 633.

182 Martha McCarthy, Students as Targets and Perpetrators of Sexual Harassment: Title IX and Beyond, 12 Hastings Women's L.J. 177, 204-05 (2001). See also Fermeen Fazal, Note, Is Actual Notice An Actual Remedy? A Critique of Gebser v. Lago Vista Independent School District, 36 Hous. L. Rev. 1033, 1062-66 (1999). 
have established deliberate indifference. ${ }^{183}$ And although courts vary in how they articulate what amounts to "deliberate indifference," it seems to require something closer to negligence, even though Davis expressly rejected the negligence label, ${ }^{184}$ than intentionally harmful conduct. ${ }^{185}$ The Davis Court described the requisite fault as a "decision to remain idle in the face of known" discrimination, or acting in a way that is "clearly unreasonable in light of the known circumstances" in terms of putting an end to the discrimination. ${ }^{186}$ Under the Court's reasoning, finding an official decision not to remedy the discrimination effectively means that the school has "caused" the discrimination for purposes of Title IX. ${ }^{187}$

Moreover, as the Court repeatedly emphasized in Davis, and in its decision one year earlier in Gebser v. Lago Vista Independent School District, ${ }^{188}$ a teacher-student sexual harassment case in which the Court first adopted this standard under Title IX, the Court only decided the standard of liability that governs private lawsuits for damages based on sex discrimination that is not official school policy. ${ }^{189}$ In other words, this liability standard applies only to Title IX damages claims where the actor engaging in the discrimination does not act as an agent of the school. In such cases, the need for such a high standard for liability was tied to the Court's concerns about holding federal funding recipients liable in private suits for damages without prior notice or opportunity to correct discrimination that was occurring in their programs via unofficial actions, possibly unbeknownst to school officials. ${ }^{190}$ The Court's reasoning confirms that a Title IX violation (as distinct from a private lawsuit for damages) may occur even without actual notice to school officials and deliberate indifference, albeit without a damages remedy. In such a case, an aggrieved person would be left to pursue alternate remedies, such as filing a complaint with the federal enforcement agency, the Office for Civil Rights (OCR), or

183 See, e.g., Simpson v. Univ. of Colo. Boulder, 500 F.3d 1170, 1184-85 (10th Cir. 2007); Vance v. Spencer Cnty. Pub. Sch. Dist., 231 F.3d 253, 262 (6th Cir. 2000).

184 See Davis, 526 U.S. at 642.

185 See, e.g., Vance, 231 F.3d at 261 (explaining that Title IX's notice and deliberate indifference standard requires a reasonable response from school officials); Mercer v. Duke Univ., 181 F. Supp. 2d 525, 540-41 (M.D.N.C. 2001), vacated in part, 50 F. App'x 643 (4th Cir. 2002), (citing authority interpreting the standard as satisfied by an official decision not to remedy a Title IX violation, and emphasizing that school districts cannot turn a blind eye and do nothing).

186 Davis, 526 U.S. at 641, 648.

187 Id. at 642-43. See also Deborah L. Brake, School Liability for Peer Sexual Harassment After Davis: Shifting from Intent to Causation in Discrimination Law, 12 Hastings Women's L.J. 5, 7-8 (2001) (explaining the actual notice and deliberate indifference standard in terms of causation).

188 Gebser v. Lago Vista Indep. Sch. Dist., 524 U.S. 274 (1998).

189 Davis, 526 U.S. at 629, 639.

190 Id. at 639-40. The Court grounded this concern in the limitations of Title IX as legislation based on Congress' Spending Clause power, which the Court viewed as equivalent to a contractual obligation with recipients of federal funds to comply with the terms of Title IX. If this "contract" would ultimately subject school districts to damages liability for discrimination taken by students, the Court reasoned, the recipient should first have notice of the discrimination and an opportunity to correct it. 
suing in court for injunctive relief. ${ }^{191}$ These alternative remedies might not have as much deterrent effect on school districts as damages (especially given OCR's track record of never having terminated federal funds for a Title IX violation and instead negotiating compliance agreements with school districts), ${ }^{192}$ but they might nevertheless bring enough pressure to prompt school officials to take action to stop the discrimination.

The other requirement in Davis for holding schools liable for discrimination by non-agents goes to the severity of the discrimination, requiring that it amount to a deprivation of access to an educational opportunity or benefit. ${ }^{193}$ That part of the Court's holding was intended to ensure that school districts would not be liable for everyday encounters between students that occurred because of a student's sex. ${ }^{194}$ At the extreme end of the spectrum, the Court analogized to male students physically preventing female students from using a school resource, such as an athletic facility. ${ }^{195}$ While clearly prohibited, the Court noted that less severe actions by students could also amount to deprivation of opportunity, including harassment so severe that it "undermines and detracts from" an educational experience. ${ }^{196}$ While no court has yet considered the issue, denying female students athletic opportunities when male opponents refuse to wrestle girls is plausibly within the range of discriminatory actions that could amount to a denial of an educational benefit or opportunity. This is especially the case where a pattern of gender-based forfeitures make for substantially less competition and skills-development for female wrestlers. One complication in the wrestling setting, not present in Davis or the peer sexual harassment cases that followed, is that the discriminator (the male opponent) and the person subjected to discrimination (the girl who is denied the chance to wrestle) will likely attend different schools, which, at least if in different school districts, may be different funding recipients for purposes of Title IX. Under the statute and OCR's interpretive guidance, however, a school has an obligation to avoid discrimination against persons who are not students when it occurs within the school's educational programs. The statute bars discrimination against any "person," and OCR has recognized that this includes all persons who come into contact with the program, listing as an example, members of visiting athletic teams. ${ }^{197}$ Since the school of the male opponent will have authority over the male wrestler who forfeits, the girl's Title IX claim would run against his school district for failing to take action to discourage genderbased forfeitures by its athletes.

191 See Revised Sexual Harassment Guidance: Harassment of Students by School Employees, Other Students, or Third Parties, 66 Fed. Reg. 5512-01 (Jan. 19, 2001) (stating OCR position that the Gebser/Davis liability standard only applies to private lawsuits for damages, and not to OCR enforcement actions or lawsuits seeking injunctive relief).

192 Sudha Setty, Leveling the Playing Field: Reforming the Office for Civil Rights to Achieve Better Title IX Enforcement, 32 Colum. J.L. \& Soc. Probs. 331, 344-45 (1999). 193 Davis, 526 U.S. at 650, 652.

194 Id. at 650-51.

$195 I d$. at 651.

196 Id.

197 See Letter from Russlynn Ali, Assistant Sec'y for Civil Rights, Dep't of Educ., Office for Civil Rights, at 4 n.11 (Apr. 4, 2011), available at http://www2.ed.gov/about/offices/list/ ocr /letters/colleague-201104.pdf. 
Depending on the particulars of how gender-based forfeitures are handled, there may be a broader pool of defendants than just the school that is responsible for the forfeiting wrestler. An athletic league or association might be shown to collude in allowing, or even encouraging, gender-based forfeitures. Where that is the case, a Title IX claim might be brought against these entities as well as the forfeiter's school district. ${ }^{198}$ Athletic associations have been held accountable under Title IX where they exercise delegated authority from federally funded schools to run their athletic programs even if the association does not itself receive federal funds. ${ }^{199}$ Some athletic associations have also been found to be state actors, subject to the requirements of the equal protection clause. $^{200}$

In any Title IX claim brought for discrimination by a non-school official, a crucial part of the claim is showing that the school had control over, and acquiesced in, the discriminatory acts. In a claim against the school of the forfeiting wrestler, this control would likely be exercised by the coach, acting with the delegated authority of the school. Athletic associations also exercise control over participants in setting the ground rules for competition. Building the Title IX claim would entail spelling out the many ways in which schools and athletic associations have control over student-athletes. The most immediate source of control is the coach. A Title IX claim would set out to show that the forfeits were done with the implicit or explicit support of the coach. Articles about wrestling and forfeiture strongly suggest that schools, primarily through coaches, and sometimes through official school policy, greatly influence the decisions of male wrestlers to forfeit to girls. ${ }^{201}$ The converse

198 For the regulatory background governing relationships between schools and other entities that control school programs, such as athletic associations, see 34 C.F.R. $§ 106.31$ (b)(6) (2011) (forbidding recipients from providing "significant assistance" to any person or entity that discriminates on the basis of sex in providing any aid, benefit or service to students); id. $\S 106.31(\mathrm{~d})$ (extending the prohibition on sex discrimination to programs operated by someone other than recipient, where recipient requires its students to participate or facilitates, permits, or considers such participation as part of or equivalent to education programs operated by the recipient); id. $\S 106.51$ (a)(3) (forbidding recipients from entering into contractual or other relationships that have the effect of subjecting employees or students to discrimination).

199 See BRAKE, supra note 18, at 152-53 (discussing split in case law regarding whether athletic associations may be held accountable under Title IX, and what circumstances would support doing so).

200 See, e.g., Cmtys. for Equity v. Mich. High Sch. Athletic Ass'n, 80 F. Supp. 2d 729, 739 (W.D. Mich. 2000). See also Brentwood Acad. v. Tenn. Secondary Sch. Athletic Ass'n, 531 U.S. 288, 298 (2001).

201 See, e.g., Stuart \& Whaley, supra note 20, at 32 (relaying stories of coaches who would have their wrestlers forfeit matches to avoid the humiliation of losing to a girl, and describing this practice as controversial; noting that some high school districts have set up rules against forfeiting matches to girls); Brunswick, supra note 62, at 1B (reporting instances of schools requiring opposing teams with female wrestlers to notify them in advance of a meet of how many girls are on the team and at what weight so they can notify parents of potential competitors, implicitly inviting forfeiture); $i d$. (statement of a wrestling coach who prohibits his wrestlers from wrestling girls) ("If we saw these same things in the hallways of the school, we'd break them up and send someone to detention ...."); Thomas, supra note 33, at D1 (describing former policy of Fauquier County, Virginia, school district-repealed Feb. 2004 - of not allowing mixed-sex wrestling, including requiring boys to forfeit if matched against girls); Nakashima, supra note 64 , at A1 ("[C]oaches often have qualms, and many 
is also true, that coaches have the authority to stop their athletes from forfeiting. ${ }^{202}$

This level of control comports with the Court's admonition in Davis that the notice and deliberate indifference standard only makes sense if the school has some control over the discriminator. Such control enables the Court to view the school's nonresponse as a "cause" of the discrimination. ${ }^{203}$ Under the theory adopted in Davis, schools are responsible for how they respond to discrimination in school programs carried out by persons under their control. ${ }^{204}$ This principle, formulated in a peer sexual harassment case, should also apply to the wrestling forfeiture phenomenon.

The remaining doctrinal question is what, exactly, schools and/or athletic associations must do to avoid being deliberately indifferent. Merely counting the forfeiture as a loss apparently does little to discourage forfeitures. With thirty to forty matches per season, one or two forfeitures to girls for an individual male wrestler is trivial, especially compared to the impact such forfeitures have, when widespread, of decimating girls' opportunities. Establishing that school officials are aware of such forfeitures, and aware that counting them as a loss does not deter them, might be enough to show deliberate indifference. ${ }^{205}$ Evidence that a coach or other official encouraged boys to forfeit matches to girls would be even stronger evidence of deliberate indifference. On the other hand, a school that requires a wrestler who forfeits a match without medical reason to forfeit the next five matches, or be disqualified from a predetermined number of tournaments, would likely clear the deliberate indifference bar. An even stronger response would make it a requirement of being on the team that

allow their players to forfeit if they're uncomfortable grappling with a girl."); Parker, supra note 36, at D1 (citing, among other instances of "outright sexism" experienced by female wrestlers, "[h]igh school coaches who ask tournament officials to rejigger the brackets to avoid coed matches"); Scott Howard-Cooper, The Preps: Parkinson Returns from Nebraska, Decides to Stay (at USC), L.A. TIMES, Feb. 5, 1985, at D8 (noting report of a school board in Pennsylvania that ordered their high school to forfeit a wrestling match rather than compete against a girl).

202 See, e.g., Garner, supra note 66 (statement of one coach) ("I've never had them say, 'I won't do it, I won't wrestle her' . . . I'm old-school. I'd tell them to get their butt out there unless they have a very good reason not to. It's a wrestler; it's not a boy or a girl. A girl is a girl . . . big deal. She's just a competitor."); K.J. Pilcher, Coaches Weigh in on Female Wrestlers, GazetTe (Cedar Rapids, IA) (Feb. 17, 2011, 3:19 PM), http://thegazette.com/ 2011/02 /17/coaches-weigh-in-on-with-female-wrestlers/ (statement of one Iowa high school wrestling coach) ("I'm not opposed to it, and I never had a kid forfeit to a girl . . I would never do that. I do prefer females wrestling females, but if they're going to strap it up in a high school season we're going to wrestle them.").

203 Davis v. Monroe Cnty. Bd. of Educ., 526 U.S. 629, 644-45 (1999).

204 The Equal Protection Clause might also provide a remedy for discrimination by students in public school programs, but the contours of such a claim have not yet been sketched out in the case law, partly because the Supreme Court only recently decided that Title IX does not preclude Equal Protection claims based on the same discriminatory conduct. See Fitzgerald v. Barnstable Sch. Comm., 555 U.S. 246, 256 (2009).

205 See Davis, 526 U.S. at 648 (explaining that this standard does not give rise to any particular remedial demands by plaintiffs, and courts will not second-guess disciplinary decisions, but that a school must do more than respond indifferently, with a course of action it knows will not end the discrimination). 
all participants abide by a policy of nondiscrimination with respect to opponents.

As this discussion shows, there is a credible legal argument that acquiescence in gender-based forfeitures violates Title IX. The more difficult question of whether such a legal claim has the potential to change the narrative that emerges from such forfeitures, and shift cultural norms in a way likely to promote gender equality, is taken up in the next section.

\section{The Construction of Masculinity and the Role of Law}

The Title IX regulations and precedents can be used to construct a legal argument that schools and possibly athletic associations violate Title IX when they acquiesce in male wrestlers' gender-based forfeitures to female opponents. The more difficult question is whether such a legal claim has the potential to challenge the gender norms and shift the message of the story away from the backlash narrative that valorizes the forfeiter. Using Title IX to force schools to punish a boy who refuses to wrestle a girl might well only add to the magnitude of the boy's sacrifice, turning his six minutes of fame on CNN into an even lengthier and more celebratory story. Cassy Herkelman — and now Title IXwould be pawns in this story, blamed for Northrup's sacrifice while he is praised for making it.

In order to effectively engage in these struggles, we who use law to challenge sex discrimination must find a way to contest the norms that sustain the traditional gender order. At the heart of the Iowa incident is the use of forfeiture as a strategy to defend and construct a hegemonic masculinity. By refusing to wrestle girls, male wrestlers have found a way to deflect the threat to masculinity posed by girls in the sport, constructing for themselves an updated form of hegemonic masculinity at the same time as protecting the masculinity of the sport itself. In thinking about the potential for law to intervene in this conflict, the core question is whether it can interrupt this construction of masculinity.

\section{A. Constructing Masculinity Through Forfeiture}

As scholars of sport and sociology studies have long recognized, sport is a powerful arena for negotiating and contesting the cultural meaning of gender. For boys and men, sport has served as a primary site (perhaps even the primary site) to construct a culturally valued masculinity, and oftentimes a hegemonic masculinity. Sport is particularly well positioned to serve this role for numerous reasons. For boys who play competitive sport, especially as they advance in age and skill level, it is typically an all-male space. This separation from girls and women reinforces the masculinizing processes of sport. ${ }^{206}$ In reality, gender is a continuum, but all-male sports portray gender as binary, associating powerful

206 Cf. Ann C. McGinley, Ricci v. DeStefano: A Masculinities Theory Analysis, 33 Harv. J.L. \& GENDER 581, 583-84 (2010) (discussing the importance of homosocial environments in which men construct and prove their masculinity to other men, and describing how the exclusion of women from firefighting, and the hazing of those who do gain access, functions to construct a hegemonic, working-class, white masculinity for the dominant group of male firefighters). 
athletic performance with the status of being male. ${ }^{207}$ The masculinity achieved through sport is entirely constructed, but the absence of women makes it appear seamless and natural.

Sport's connection to nationhood further clothes its male participants with a warrior-like, masculine status. Symbolic competitions are performed on a public stage, where pride of locale is pitted against representatives of some other community, whether it is school, town, or nation. In these all-male spaces, athletic performances both symbolize and naturalize a dominant, physically-aggressive masculinity, especially in contact sports. The masculinizing status of sport is widely available to boys starting at young ages and continuing into young adulthood through school and community programs.

The introduction of women into male sports problematizes these connections. As sport and gender scholar Teresa Walton explains, when women participate in contact sports such as wrestling, "their inclusion needs to be accounted for culturally." ${ }^{208}$ The presence of women as participants and competitors interrupts the masculinizing work of sport. This is partly because, as masculinities scholars have explained, masculinity is defined more by what it is not than by what it is. Above all, masculinity is defined as being oppositional to femininity. ${ }^{209}$ Hegemonic masculinity, in particular, requires sharp differentiation from the feminine. Although hegemonic masculinity presents itself as allpowerful, in actuality it is fragile in that it cannot be achieved once and for all. ${ }^{210}$ It is "the big impossible," never stable, never at rest. It must always invest great effort to fend off challenges.

Just as hegemonic masculinity is never stable in the individuals who possess it (and must at all times be defended from threats), the masculinity that is hegemonic in a particular context is not stable or fixed in time. It is situational and historical. The masculinity that is hegemonic among white-collar, professional men is different from the masculinity that is hegemonic among workingclass, blue-collar workers. ${ }^{211}$ This is no less true in sport. Football players vie for a hegemonic masculinity that differs from the masculinity that is constructed by playing baseball, which differs still from the masculinity achieved through success in golf. ${ }^{212}$ Even in a particular setting, hegemonic masculinity is not fixed but fluctuates over time.

The threat to masculinity posed by girls on the mat is evident in the common refrain, often expressed in news coverage of coed wrestling, that boys have nothing to gain from wrestling a girl, only something to lose. The dilemma was pointedly expressed by one male wrestler interviewed for a news article: "Wrestling a girl, it is a no-win situation for a guy .... In high school, if you lose to a girl, it's like, dude, you got beat up by a girl. And if you beat

207 For a discussion of gender as a continuum, see Navah C. Spero, Note, Transgendered Plaintiffs in Title VII Suits: Why the Schroer v. Billington Approach Makes Sense, 9 ConN. Pub. INT. L.J. 387, 393-94 (2010).

208 Walton, supra note 14, at 54.

209 Ann C. McGinley, Erasing Boundaries: Masculinities, Sexual Minorities, and Employment Discrimination, 43 U. Mich. J.L. Reform 713, 721 (2010).

$210 I d$. at 721-22.

211 See McGinley, supra note 206, at 586-87.

212 See Brake, supra note 73, at 210. 
them, it's like, dude, you beat up a girl."213 The adults interviewed in these stories confirm the dilemma. As one wrestling coach succinctly put it: "There's nothing that can be gained by a guy wrestling a girl." 214 The typical silverlining spin of "it will toughen him up," that frequently accompanies a loss to another boy, is absent when the winning competitor is a girl. Indeed, the cost to masculinity from being beaten by a girl is much greater for wrestling, a warrior/ contact sport, than in a non-contact sport such as swimming or tennis.

In this no-win situation for male wrestlers, forfeiters like Northrup have found a way to not only defend but affirmatively construct a hegemonic masculinity when confronted with a female opponent. It is an updated form of hegemonic masculinity in a contact sport: not "the bruiser" who attains masculinity through displays of force and vanquishing his opponents, but a chivalrous masculinity that relies on the assertion of feminine vulnerability and the need to protect it. Not fighting for another reason, such as pacifism or injury, might undercut a warrior's masculinity, but not fighting a woman in order to protect her demonstrates valor in a warrior. As one opinion-editor commented in reaction to the Northrup forfeiture: "Now that's a real man. I love his instinct. Real men physically protect women. And our society should back [him] up on it."215

In the refusal to wrestle a girl, the femininity that is protected is one that is historically linked to white women, the objects of male protection. The wrestling context does nothing to break this historic linkage, since wrestling is an overwhelmingly white sport, for girls as well as boys (and particularly so in a state like Iowa). That the femininity being protected is implicitly a white femininity makes the masculinity that protects it all the more valuable. And the fact that the forfeiter pays a price for his decision to protect instead of fight his female opponent, in the form of giving up his chance to win the tournament, makes his masculinity (like that of a warrior) all the more prized. Much of the appeal of Northrup's invocation of religion is that it aligns with a noble warrior masculinity based on chivalry and sacrifice.

Forfeiture not only constructs a hegemonic masculinity for the male wrestler, it also preserves the masculinity of the sport itself. As previously discussed, the intrusion of women into the sport brings concerns about sexuality and intimacy to the forefront, threatening the hetero-masculinity of the sport, which depends on an asexualized understanding of the sport. Sport scholar Teresa Walton has noted that the sport's vulnerability to sexualization has made it a particularly homophobic sport. ${ }^{216}$ Wrestling strives to maintain an image as an aggressive sport that is void of any sexual connotations or homoerotic aesthetic. Not wrestling women protects the sport from being contaminated by the perception of sexuality.

As masculinities scholars have pointed out, not all masculinities are equally harmful to women and less masculine men, nor are they similar in relation to gender equality. Some masculinities are more subordinating than

213 Parker, supra note 36, at D1.

214 Andy Resnik, Female Wrestlers Face Uphill Battle, Associated Press St. and Loc. WIRE, Feb. 28, 2001, at Sports News, available at http://www.lexisnexis.com/lnacui2api / delivery/PrintWorking.do?dnldFileName=Female_wrestlers_face_uphill_battle.

215 Hart, supra note 4 , at 4.

216 Walton, supra note 14 , at 59. 
others. The masculinity constructed through forfeiture is a hegemonic masculinity that is incompatible with gender equality in sport, relying as it does on a construction of femininity that is in need of protection and deficient in agency. Imposing on women in sport the norms of a Victorian femininity contributes to the "female apologetic" in which high-level female athletes must defensively emphasize a conventional femininity in order to make up for a loss of femininity from participation in sport. ${ }^{217}$ The apologetic stems from the thick connections between sport and masculinity; if sport masculinizes its participants, female athletes experience a role conflict when they excel at sport. Forty years of a post-Title IX world has greatly altered this conflict for female athletes, but it still exists when female athletes push the boundaries of cultural comfort, as girls and women do when they wrestle. Articles about girls in wrestling reflect this in their frequent references to female wrestlers' femininity. Teresa Walton, in her review of media coverage of girls' wrestling, found that the stories focused more on the girls' femininity than their wrestling skill. ${ }^{218}$ Reporters went out of their way to depict the girls as feminine, having boyfriends, being "girly," sporting long hair and make-up, and wearing dresses, despite being tough in the ring. ${ }^{219}$ Performance of the apologetic reinforces the legitimacy of male privilege and preserves sport as a primarily male domain in which women are interlopers. The femininity that is reflexively constructed by forfeiture's construction of masculinity is incompatible with an equal role for girls and women in sport.

Equally important, forfeiture also subordinates alternative masculinities to the newly hegemonic ideal that it constructs in the male wrestler who forfeits. By valorizing a forfeiter like Northrup, the boys who do wrestle girls, whether they win or lose, are left with a more tarnished masculinity by comparison. When the CNN interviewer congratulates Northrup for his decision, an implicit comparison to the boys who do wrestle girls is unavoidable. As masculinities scholars note, how men compare to other men is as or more important as men's relationships to women in constructing masculinity.

The stories of boys who are celebrated for wrestling girls are few and far between. And yet, buried in the stories of coed wrestling, there are occasional references to boys who become comfortable with the decision to wrestle girls and appear to accept girls as equal competitors. One accomplished male high school wrestler recalled wrestling a girl in his first match as a freshman: "Having to wrestle a girl, my mindset was just to wrestle whether it was a girl or anybody else . . . . I wouldn't have liked to lose to a girl, but I don't want to lose anyway, whether it's a girl or guy." ${ }^{220}$ A high school boy who lost several times during the season to the girl who won Vermont's state championship expressed respect for his female competitor: "I respect her more because she's dominant in a male sport .... She has the best technique of anyone I've

217 See Mary Jo Kane, Media Coverage of the Post Title IX Female Athlete: A Feminist Analysis of Sport, Gender, and Power, 3 Duke J. Gender L. \& Pol'y 95, 121 (1996) (discussing the female apologetic in sport).

218 Walton, supra note 14 , at 60.

219 See id. at 60-61.

220 Garner, supra note 66. 
wrestled at $103[\mathrm{lbs}.] .{ }^{221}$ Some girls too tell stories about winning respect from male teammates and competitors. Two female high school wrestlers in Indiana described initial resistance to their entry into the sport, followed by acceptance. "At the beginning of the season, we were like outcasts from the team, but now we're good friends . . . . They respect us and we respect them." ${ }^{\text {"22 }}$ A female high school wrestler from Maryland described her male teammates as "unanimously accepting" of her, saying, "the team will definitely back me up for anything." "223 Her coach expressed surprise that "there are still coaches who have their wrestlers forfeit rather than compete against [her]," stating, "I thought we were past that." ${ }^{\text {"22 }}$ The final section considers whether law might intervene to incentivize and encourage these alternative, more egalitarian masculinities.

\section{B. A Role for Law? Incentivizing Alternative Masculinities in Sport}

Nancy Dowd has urged feminist legal scholars to "ask the man question": what masculinity is being constructed here? 225 I would follow up that question by asking, is there a role for law in destabilizing hegemonic masculinity and encouraging alternative, more egalitarian masculinities? Precisely because hegemonic masculinity is fluid and not fixed, there is the potential to subvert it and open up greater space for alternative masculinities to flourish and become culturally valued. What role might law play in this effort? There is no easy answer to this question, and the best I can do at present is to offer some preliminary thoughts.

Since sacrifice is a core part of the hegemonic masculinity being constructed by forfeiture, using Title IX to raise the stakes for the forfeiter risks adding to his valor. Requiring school or league officials to impose successively greater punishments on the wrestlers who refuse to wrestle is unlikely to change the gendered meaning of forfeiture. It would more likely only further undermine support for girls in wrestling, and for Title IX. Reva Siegel, in a recent article on what she perceives as an "antibalkanization principle" in equality law, cautions against remedies that are divisive and corrosive to equality rights. ${ }^{226}$ She urges instead a search for transformative remedies that increase social cohesion and cultivate understandings of gender that "sustain social commitments" to the project of gender equality. ${ }^{227}$ Operationalizing this principle is no easy task, but in this instance it might entail incentivizing those boys who are courageous enough to wrestle girls, win or lose, instead of punishing the boys who refuse. This could be done by using the deliberate indifference standard not to force schools to discipline the forfeiter but, rather, to respond by creating an environment that supports and encourages the equal

221 Longman, supra note 3, at D1 (internal quotation marks omitted).

222 Patel, supra note 48, at 4 (internal quotation marks omitted).

223 Young, supra note 68, at ME18.

224 Id. (internal quotation marks omitted).

225 Nancy E. Dowd, Asking the Man Question: Masculinities Analysis and Feminist Theory, 33 Harv. J.L. \& GENDER 415, 415 (2010).

226 Reva B. Siegel, From Colorblindness to Antibalkanization: An Emerging Ground of Decision in Race Equality Cases, 120 YALE L.J. 1278, 1278 (2011).

227 See id. at 1358. 
treatment of girls in wrestling. That is, instead of punishing forfeiters, the Title IX duty to respond to discrimination could be met through a concerted effort by school officials to encourage respect and equal treatment for all opponents. In an initial team meeting, coaches could set the tone, expressing disapproval of forfeiture, and insisting on respect for female wrestlers, whether as teammates or opponents. This could even be made a principle of team membership, that in order to be a member of the team, every participant must be willing to give their best effort against every opponent. At the same time, coaches can make clear that they will not tolerate any teasing, hazing, or belittling of wrestlers for any reason, including when directed against boys for wrestling a girl. If, despite these conditions, a forfeiture occurs anyway, and a girl is left without an opponent, the coach might offer praise and incentives for a wrestler (in the same weight class) to step up and take his place. (Tournament rules may need to be adjusted to permit this-e.g., by allowing/encouraging a wrestler who has been disqualified to fill in for a forfeit.) While the particulars of the response by the coach, school, and league may vary, the point is that punishment should not be the only way to avoid a deliberately indifferent response to the discrimination in opportunities. A team meeting endorsing the principles of respect and equal treatment of opponents could go a long way toward minimizing gender-based forfeiture without martyring a boy for refusing to wrestle a girl.

Such an interpretation of deliberate indifference is well within existing legal interpretations of this standard. Indeed, Title IX's deliberate indifference standard has been criticized for being too deferential to school officials. ${ }^{228}$ Courts have repeatedly held that this standard does not require an actual end to the discrimination, just a concerned (that is, a non-deliberately indifferent) response. ${ }^{229}$ While these critiques are persuasive in many cases-such as those involving rape by student-athletes, followed by minimal efforts to rebuke star athletes - in this instance, the flexibility of the deliberate indifference standard could be an asset. A more flexible approach of incentivizing male wrestlers to wrestle girls is likely to have greater cultural impact in changing gender relations-both in developing more egalitarian masculinities among male wrestlers and in generating respect for female wrestlers - than a strict practice of penalizing boys for refusing to wrestle girls. ${ }^{230}$ It is also more likely to lead to the kinds of sport experiences between girls and boys that are likely to generate feelings of mutual respect-a respect that can spill over into other dimensions of social life.

With this interpretation of the deliberate indifference standard, the Title IX claim might productively intervene in the gendered meaning of forfeiture. One benefit of using Title IX in this way is that it would bring into the conversation

228 Susan P. Stuart, Jack and Jill Go to Court: Litigating a Peer Sexual Harassment Case Under Title IX, 29 Am. J. Trial Advoc. 243, 276 (2005). See also Fazal, supra note 182, at 1060-61.

229 See, e.g., Davis v. Monroe Cnty. Bd. of Educ., 526 U.S. 629, 648-49 (1999); Williams ex rel. Hart v. Paint Valley Local Sch. Dist., 400 F.3d 360, 367 (6th Cir. 2005); Wills v. Brown Univ., 184 F.3d 20, 41 (1st Cir. 1999).

230 See generally Dan M. Kahan, Gentle Nudges vs. Hard Shoves: Solving the Sticky Norms Problem, 67 U. CHI. L. REv. 607, 607-46 (2000) (discussing small changes legislators can make to help dissolve gender barriers). 
the impact forfeiture has on girls' athletic opportunities, making female wrestlers' experiences a more central part of the story. The claim would also bring into the foreground the many ways in which coaches and other school officials create the conditions that shape wrestlers' choices about whether to wrestle, exposing the myth of complete agency by the male wrestlers who forfeit. Most importantly, in practice, the resulting legal pressures would hopefully encourage an environment that is more appreciative and accepting of the male wrestlers who do treat female opponents as legitimate competitors. As their stories become known, and their experiences are normalized through team culture and coaching expectations, a new narrative of forfeiture may emerge.

In addition to using Title IX directly to respond to forfeiture, there may be other, indirect ways to use law to push back against the production of this kind of hegemonic masculinity in sport. This is at best an uphill battle, but in the interest of beginning a dialogue, I will suggest three fronts where greater use of law and legal strategy might eventually be productive. First, the utter absence of women in leadership positions over men's sports is enormously significant in making men's sports a site where hegemonic masculinity is produced. Many commentators have lamented the decline of women coaches in women's sports in the post-Title IX era, but the virtual absence of women coaching men, both before and after Title IX, is taken for granted. Even the tepid liberal equality standard in sex discrimination law as applied to hiring (both under Title VII and Title IX), if seriously enforced, should open doors for at least some women to coach male sports teams. It simply cannot be the case that "the best person for the job" of coaching boys and men is always a man. Well-qualified women coaches should be encouraged to apply for jobs coaching male athletes, and the federal enforcing agencies (both the EEOC and OCR) should step up their efforts to make sure that the nondiscrimination laws are fully enforced when it comes to hiring coaches for male teams. The experience of having a female coach could do more than anything else to subvert the role of sport in constructing hegemonic masculinity. With women as leaders and teachers in sport, male athletes would learn a form of sport that is consistent with respect for women and be more likely to develop masculinities that are not dependent on subordinating women. This will not happen overnight (if ever), but it is a goal worth pursuing.

Second, as I have argued elsewhere, Title IX's bright-line differentiation of the integration rights available to female and male athletes should be revisited. Under current law, female athletes, as the underrepresented sex, have a right to try out for a team in a sport offered only to male athletes (under Title IX, if it is not a contact sport; and under the equal protection clause, if it is a public school, regardless of whether it is a contact sport $^{231}$ ). Male athletes, however, are not typically the underrepresented sex and so do not have a right to try out for a female team in a sport not offered to them. While this asymmetry accords with the goal of preserving limited opportunities for women, the underrepresented sex, it does not adequately take into account how the narrow range of sport choices available to boys aligns with culturally valued masculinities. That is, boys' sport choices are generally limited to sports requiring great

23134 C.F.R. $§ 106.41(b)(2011)$. 
strength, speed, and size-football and basketball, especially-and sports that are culturally valued as masculine. Boys are generally not offered the wide range of sport choices available to girls. While it is true that boys' overall opportunities in sport still outnumber those of girls, there is a significant value in giving boys a broader range of playing opportunities and thereby widening the range of sporting experiences, styles, and ultimately, masculinities available to boys. Boys should not be stigmatized for playing "girls' sports" like volleyball or field hockey, if they can be included without too deep an incursion into girls' opportunities. In making these trade-offs, we should consider more carefully the way the gendering of sports contributes to the narrowing of the masculinities available to boys in sport.

Finally, Title IX may offer a way to police at least the outer limits of a violent hegemonic masculinity in sport. Title IX's hostile environment harassment claim may require schools to respond more proactively to prevent and eradicate the most hyper-masculine excesses of male locker-room culture. For example, a 2009 district court decision recognized a Title IX claim for the sexual hazing of male freshman by more senior high school students at a school-sponsored football camp. ${ }^{232}$ The case stemmed from the actions of several players at the camp who sexually assaulted their younger teammates with an air pump. ${ }^{233}$ This and other sexually harassing and homophobic conduct prompted one of the victims to bring a Title IX lawsuit against the school for its indifferent response to these harmful behaviors. ${ }^{234}$ The court found that the issues of actual notice and deliberate indifference were close ones but denied the school's motion for summary judgment based on evidence that the football coach, who initially viewed the behavior as childish "horseplay," may have had notice, and may have been too slow to respond. ${ }^{235}$ Most significantly, the court rejected the argument that the misconduct was simple hazing and did not amount to discrimination based on sex. The court noted that "the homophobic language used by the perpetrators appears to be part of a larger constellation of sexually-based conduct, which included assaulting Plaintiff with an air hose, exposing their genitalia, and grabbing his bare buttocks in the shower," and concluded that such allegations could conceivably show that "the conduct at issue relate[s] to gender." 236

This court's decision marks an important turnaround from the understanding that prevailed in the previous decade, as reflected in a Tenth Circuit decision, Seamons v. Snow. ${ }^{237}$ In that case, the court held that a similar enactment of hyper-masculinity between male athletes did not constitute discrimination based on sex. It upheld the dismissal of a Title IX complaint brought by a male high school football player who was sexually harassed in the locker room by his teammates. ${ }^{238}$ In that case, as he was coming out of the shower, Brian Seamons was grabbed by five upper-class football players who tied him, naked,

232 Roe v. Gustine Unified Sch. Dist., 678 F. Supp. 2d 1008, 1039 (E.D. Cal. 2009).

233 Id. at 1013.

234 Id. at 1015.

235 Id. at $1038-39$.

236 Id. at 1027.

237 Seamons v. Snow, 84 F.3d 1226 (10th Cir. 1996) [hereinafter Seamons II].

238 Id. at 1239. 
to a horizontal towel bar with athletic tape, and then brought in a former girlfriend to witness his humiliation. The coach viewed the incident as part of the normal "boys will be boys" culture of athletics. ${ }^{239}$ After Brian reported the incident to school authorities, the football coach accused Brian of betraying the team, saying he "should have taken it like a man." apologize, the coach cut Brian from the team; the assailants went unpunished. In response to Brian's complaints that nothing was done, the school district cancelled the final game of the season, a state play-off game. Brian was vilified for this decision, subjected to threats and harassment, and the principal suggested he leave the school. Fearing for his safety, Brian transferred to another school. ${ }^{241}$

Despite the deeply gendered nature of these events, the district court dismissed the Title IX complaint on the ground that none of this amounted to sex discrimination. ${ }^{242}$ The Tenth Circuit affirmed, explaining that notwithstanding the coach's statements that Brian should have taken it "like a man," "[t]he qualities Defendants were promoting, team loyalty and toughness, are not uniquely male," and there was no evidence that a female victim of harassment by these players would have fared any better. ${ }^{243}$

The difference in these two decisions holds promise for the law's potential to curb the violent excesses of hegemonic masculinity in the locker room. The court deciding Roe grasped something that the Tenth Circuit in Seamons did not: that such performances are very much about gender. The assailants in both cases constructed hegemonic masculinity through domination of subordinated masculinities, the unproven lower classmen. Their victims were expected to take it "like men" by enduring the aggression instead of reporting it. This is a common locker-room-hazing ritual in male sports, in which novice male athletes are inculcated into the norms and culture of hegemonic masculinity by enduring ritualized bullying and aggression by higher-status athletes. ${ }^{244}$ Their complicity is purchased with the understanding that they will ultimately inherit the right to claim hegemonic masculinity themselves, once they are upperclassmen. The fact that female students might also be brutalized in this environment (including by high-status male athletes claiming a right of sexual access to women as part of the privilege of hegemonic masculinity) does not "de-gender" this process. ${ }^{245}$ Hegemonic masculinity subordinates women, as well as lessmasculine or non-conforming men.

The path from Seamons to Roe reflects some progress in judicial understanding of the gendered harms in men's sports, and places institutional responsibility in schools to do something to curb the most extreme abuses. The

\footnotetext{
239 Id. at 1230.

$240 I d$.

241 Id.

242 Seamons v. Snow, 864 F. Supp. 1111 (D. Utah 1994), aff'd in part and rev'd in part, 84 F.3d 1226 (10th Cir. 1996).

243 Seamons II, 84 F.3d at 1233.

244 Richard Light \& David Kirk, High School Rugby, the Body and the Reproduction of Hegemonic Masculinity, 5 Sport, Educ. \& Soc'y 163, 163, 168-69 (2000).

245 Indeed, there are plenty of examples of this. See, e.g., Simpson v. Univ. of Colo. Boulder, 500 F.3d 1170, 1183 (10th Cir. 2007) (discussing incidents of hazing and harassment of a female football player, Katharine Hnida, at the University of Colorado).
} 
potential for this claim to transform the construction of masculinity in sport, however, is likely quite limited. Such a use of Title IX punishes only the most vicious enactments of hegemonic masculinity; it does not directly support or promote the development of alternative, more democratic masculinities-masculinities that can support, or at least co-exist with, gender equality. Still, the juxtaposition of these two cases suggests that there is some potential for law to disrupt the socialization process that constructs a harmful and subordinating hegemonic masculinity in men's sports. By policing the outer limits of abusive behavior by male athletes, whether it targets men or women, Title IX may pressure school officials and athletic administrators to cultivate locker-room cultures with more space for alternative masculinities to develop and flourish.

\section{Conclusion}

The Iowa forfeiture story, as told by $\mathrm{CNN}$, represents a successful pushback against a woman's incursion into the male domain of sport. It is "preservation through transformation" 246 in action: out of a gender crisis, an updated form of hegemonic masculinity is constructed and valorized, while women and the men who accept them on equal terms are marginalized and subordinated. The maneuvering that accomplishes this is classic, and holds important lessons for how the gender culture wars are fought and won. Through the four moves discussed in this Article - the interjection of religion, the assertion of differential agency, the appearance of neutrality, and the strategic deployment of mainstreamed and co-opted feminism - a threat to the gender order is averted.

Although the contest over gender in sport-and gender in society more broadly - is not openly acknowledged in prevailing cultural narratives as being about a defense of hegemonic masculinity, masculinity is very much at the heart of the struggle. It is the effort to reconstruct and defend hegemonic masculinity that fuels the fires of gender culture wars, and the normative masculinity that emerges from this struggle determines the possibilities for pursuing more equal gender relations. The story of the Iowa forfeiture reveals much about how hegemonic masculinity can be constructed out of a backlash. As R.W. Connell explains, most of the time, the defense of patriarchy does not require an explicit politics of masculinity; rather, the defense is typically accomplished through the "routine maintenance" of institutions. ${ }^{247}$ As Connell elaborates, "Most of the time masculinity need not be thematized at all. . . Through the everyday working of institutions defended in such terms [as national security, religion, corporate profit, etc.], the dominance of a particular kind of masculinity is achieved." 248 However, in times of crisis in the gender order, there is an "interplay" between such routine maintenance and the politics of masculinity. ${ }^{249}$ In the media and other sites where contests over cultural meaning take place, political struggles over masculinity play out, as Connell

246 See Siegel, 1996, supra note 133, at 2119.

247 R. W. Connell, Masculinities 212 (2d ed. 2005).

248 Id. at $212-13$.

249 Id. at 213. 
explains, through "the promotion of exemplary masculinities."250 That is exactly the phenomenon that is occurring through forfeiture, which emerges as a strategy for regrouping and reclaiming a hegemonic masculinity in the face of the threat to established gender meanings posed by the influx of girls into the sport.

For feminist legal scholars, the most difficult part of dissecting a backlash against gender equality is the question of what law can do about it. Answering this question requires attention to the masculinities being constructed, and how law might help destabilize hegemonic masculinity and support alternative masculinities more compatible with gender equality. Finding ways to use law to promote masculinities that do not depend on the subordination of women and nonconforming men is no small task, but it is essential if law is to play a significant role in constructing more equal gender relations.

$250 I d$. at $213-15$. 